Newfoundland and Labrador Studies

\title{
Thomas Cochrane and Newfoundland in the 1820s
}

\section{Pam Perkins}

Volume 29, Number 1, Spring 2014

URI: https://id.erudit.org/iderudit/1062247ar

DOI: https://doi.org/10.7202/1062247ar

See table of contents

Publisher(s)

Faculty of Arts, Memorial University

ISSN

1719-1726 (print)

1715-1430 (digital)

Explore this journal

Cite this document

Perkins, P. (2014). Thomas Cochrane and Newfoundland in the 1820s.

Newfoundland and Labrador Studies, 29(1). https://doi.org/10.7202/1062247ar viewed online.

https://apropos.erudit.org/en/users/policy-on-use/ 


\section{DOCUMENT}

\section{Thomas Cochrane and Newfoundland in the 1820s}

\section{PAM PERKINS}

The journals of Thomas Cochrane, Governor of Newfoundland from 1825 to 1834, have never attracted much attention, even though Cochrane oversaw a significant period of transformation in Newfoundland social and political life. Cochrane's governorship marked a historic turning point since Newfoundland had been under British naval administration through 1824, with the commanderin-chief of the Newfoundland station serving as governor. That changed under the terms of the 1825 Royal Charter, which granted the island formal colonial status and transferred authority to a civil administration. Cochrane, the first Governor under the new system, arrived in Newfoundland with what appears to have been an ambitious agenda for transforming the colony: he wanted new roads and increased access to schools and churches for those outside St. John's. ${ }^{1}$ He also attempted (unsuccessfully) to incorporate a municipal government in St. John's, and he oversaw both the opening of the Supreme Court and the establishment of a government council made up of local military and civilian dignitaries. Yet his appetite for innovation and reform had limits, and when the British government, against his wishes, established a representative assembly in 1832 the immediate result was little more than a steady stream of disputes between the elected members of the assembly and Cochrane's appointed council. 


\section{Perkins}

The ensuing political stalemate, added to increasing discontent about the enormous sums of money Cochrane was pouring into the construction of Government House, led to the collapse of his administration and his recall to England. Throughout much of this eventful governorship, Cochrane was keeping a semi-regular private journal, and even though his entries tend to focus on his personal life and views rather than his political work, the journals can still offer readers today intriguing glimpses of Newfoundland society during this key period in the island's history. ${ }^{2}$

Now owned by the National Library of Scotland, Cochrane's journals fill seven volumes, covering 1824 through 1836. There are major gaps between mid-July 1829 and early April 1830 and from early August 1833 until midOctober 1835; in addition, some shorter periods include few or no entries. The entries that Cochrane made while stationed in Newfoundland range from comments on local society, to notes on (or complaints about) the weather, to descriptions of landscape and accounts of his social engagements. It is primarily the physical and social world that he documents, and even though elements of his political and professional life seep in, Cochrane appears uninterested in using his journal to duplicate or round out the sort of information he was providing in his public correspondence - an observation that might be reinforced by the fact that the most significant lapse in his journal-keeping occurs during the troubled period around and after his departure from Newfoundland. The strictly informal, private nature of the journal is also implied by Cochrane's decision to leave his work unrevised and in manuscript. While two of his first cousins - his namesake the tenth Earl of Dundonald and the naval officer John Dundas - published books drawn from similar notes and records of their travels in the service of their country, ${ }^{3}$ Cochrane apparently had no interest in making a literary name for himself. Yet precisely because the journal entries were written at or near the time of the events he was recording and were never revised for publication, they have an immediacy often missing from more polished, formal accounts of the island, and they offer what is now an unfamiliar perspective on life in 1820s St. John's. Even if - like any strictly private document - they are at times obscure or repetitive, they deserve attention as a picture of a place and a society that, in Cochrane's eyes, merge comfortable British provincialism with the exoticism of the wild and the remote.

That said, the neglect of the journals is not entirely surprising. The handwriting ranges from reasonably clear to scrawled and nearly illegible, and references to people and events can be cryptic, especially if Cochrane was touching on sensitive matters. The financial improprieties that resulted in the removal 
from office of Judge John William Molloy preoccupied Cochrane during the late summer of 1826, for example, but aside from one entry that goes into some detail on the subject (5 September), Cochrane limits himself to a few oblique references to the case. ${ }^{4}$ There is also, and perhaps inevitably in a private document of this sort, a lot of repetition of mundane details: days go by in which Cochrane records merely, and without elaboration, that he dined with one or another of his acquaintances, or that he walked to Virginia Water, or that the weather was too hot, or too cold, or too wet. Yet Cochrane is also capable of writing strikingly about some of the new phenomena and practices he encounters in Newfoundland - a silver thaw, a beaver dam, or the rowdy celebrations when townspeople bring in a "haul" of wood for the Catholic bishop. No less importantly, he also travelled around the island and, in addition to his accounts of St. John's society, he provides what are among the relatively few surviving descriptions of some of the more remote coastal communities during the early decades of the nineteenth century.

The main problem in bringing Cochrane's journals into print is the sheer amount of material. The six volumes covering the years in Newfoundland total more than 1,100 pages, making substantial cuts unavoidable. The choice of what entries to include is not always obvious, either: the tumultuous period before Cochrane was finally recalled to England is missing entirely, and he apparently overlooked historical moments that now seem significant to us. Shawnadithit's death passes without a mention, for example, even though it attracted contemporary attention in Britain as well as Newfoundland (her obituary appeared in the 14 September 1829 edition of the London Times). I have attempted to resolve some of these problems by limiting my selections to entries made during the two years between Cochrane's arrival in St. John's and his departure for his first leave to Britain. This initial residence provides a clearcut beginning and ending within the larger framework of the journal as a whole; in addition, the entries provide a good, representative sample of Cochrane's interests and pursuits. Even more importantly, they provide Cochrane's initial reactions to matters such as the landscape, the society, and the weather, subjects that form the groundwork of travel writing both then and now but that he appears to have thought less worth notice as he became more used to them. Finally, the entries that Cochrane made during those first two years stand out because they include not just day-to-day observations but also some more-orless sustained passages of narration. The excerpts included here focus on a few significant events that preoccupied Cochrane over this period: his sentimental love affair with a young woman staying at Government House during his first 


\section{Perkins}

spring and summer on the island; his travels around Conception Bay the following autumn; and his voyage along the Burin Peninsula and the south coast as far as Burgeo just before he returned to Britain in the autumn of 1827.

When Thomas Cochrane (1789-1872) arrived in St. John's on 11 October 1825, he was a 36-year-old widower, a member of a large family of impoverished but ambitious Scottish aristocrats, and he had already seen nearly 30 years of naval service. Having entered as a "volunteer" at the age of seven under the command of his father, Admiral Sir Alexander Cochrane, the younger Cochrane rose quickly through the ranks. He assumed his first command when barely 17, a career trajectory that the naval historian John Knox Laughton (writing in the original Dictionary of National Biography), considered a particularly "flagrant" example of the "gross jobbery" then pervading the navy. Yet notwithstanding the many question marks that there might have been about Cochrane's dazzling professional ascent, he came to Newfoundland with a long and varied service career behind him, having fought in the Napoleonic Wars and the War of 1812 and, in the years that followed, having served as a commander in the West Indian and North American stations. Whether the appointment to the governorship of Newfoundland marked yet another advance in Cochrane's remarkable career, however, might have been a matter of debate.

Nobody who had been paying attention to the relatively few appearances Newfoundland made in the British press during the 1810s and 1820s would have thought the island a particularly easy or pleasant posting. Almost all of the coverage of St. John's during the decade before Cochrane's arrival was of the fires that had ravaged the city in 1816,1817 , and 1819, with accounts in the Times offering highly charged pictures of "naked" victims "shivering in the storm and snow" and of thousands of desperate, homeless people facing a winter "more searching and rigorous than any thing with which we are acquainted in Europe, south of the Arctic Circle."6 In the summer of 1817, British readers were told that Newfoundlanders were in "the greatest possible distress . . for want of the common necessaries of life"; a few months later, there was a report that the "starving population" of St. John's had transformed the city into a den of "lawless banditti." At least some of the officers and civil servants stationed in Newfoundland might have agreed with this picture of it as a uniquely miserable and unwelcoming part of the British world; an undated letter in Cochrane's correspondence, from a Mr. Ayre, pleads for Cochrane's help in finding a post off the island. "I would," Ayre declares dramatically, "prefer being a 
Chimney Sweep, almost, in England, or any temperate climate to any thing that would be given me here."

Indeed, Cochrane himself, in his official and quasi-official reports on Newfoundland to his superiors in Britain, was hardly any rosier in his views than the unhappy Mr. Ayre. Writing to the politician Thomas Hyde Villiers a year after his arrival, Cochrane lamented that even though Newfoundland was "the oldest Colony in the King's possession" and ranked as high as fourth or fifth "in a commercial point of view," it "remained in a perfect state of nature absolutely as if the whole population had just fallen from the clouds . . . without public buildings ... without civil institutions ... a and I may further add almost without laws." His opinion did not appear to have improved some two years later when, in an October 1828 letter to Sir George Murray, he complained that the "bad climate, and long and dreary winters, and other causes" meant that even the colonial elite in Newfoundland faced extreme "privations."

Yet the journal presents a rather different picture of elite life in 1820s Newfoundland than Cochrane offers in his more public writing. There are, of course, a number of complaints about the unpleasant or inconvenient aspects of daily life, ranging from a drunken cook to the bone-chilling cold. Even so, St. John's appears from the beginning to have been something of a pleasant surprise, very far from the desolate, hardscrabble outpost that Cochrane was apparently expecting after having heard it "so ill spoken of." After attending morning services on his first Sunday in the city, he noted in his journal on 11 October 1825 that, with its "many well dressed females" and its "very respectable preacher," the "Church and congregation much surpass[ed] my expectations." He also approved of the "picturesque" landscape and was "astonished to find so good a street as the main street," with its large "quantity of very good shops." Later, he presents St. John's as the site of reasonably elegant social pleasures, as he turns his attention to his "rural" retreat at Virginia Cottage, where he spent much of his time during his first spring and summer in Newfoundland. His accounts of entertaining his lady visitors by arranging for a military band to provide music for them "among the trees" (26 June 1826), or of lazy afternoons of angling and wandering through decorative walks, verge on a pastoral fantasia at odds with the rough, lawless world depicted in his official correspondence.

Of course, the social world of St. John's was not the only aspect of Newfoundland to attract Cochrane's attention: during the period covered in these selections he also made two tours of the more remote settlements, in September 1826 travelling through Conception and Trinity Bays and around Random Island and then in the summer of 1827 around Placentia Bay, the Burin Peninsula, 


\section{Perkins}

and down the south coast to Burgeo and Ramea Island. His main purpose on those tours seems to have been inspecting the fishing establishments and the harbourage, and many of his entries consist of observations about the depth or commodiousness of the harbours and other such utilitarian matters. On occasion, however, he takes up more conventional topics of travel writing, including the beauties of the landscape and the lives and living conditions of the people he encounters.

The result is a sharply bifurcated version of Newfoundland. On the one hand, there is the pleasant, even cosmopolitan, world of the St. John's elite, made up of military and administrative personnel, many of whom like Cochrane himself had spent itinerant lives around the various outposts of empire. Among his inner circle during those first two years in St. John's, Cochrane encountered men and women who would have been as familiar with and as at home in the Caribbean or the East Indies as they were in Newfoundland. Members of the Skinner and the Haly families, for example, moved among Newfoundland, Gibraltar, and India, while David Buchan had established a name for himself as an Arctic explorer on the 1818 Spitsbergen expedition that also included John Franklin. At the other extreme were the inhabitants of the more remote outports, who had never managed to range much beyond the small cove or island on which they or their parents had settled.

In these selections, I have tried to highlight this range and variety of Cochrane's Newfoundland experiences. While I have included a number of relatively self-contained passages - his arrival and first impressions of the island, his account of the Bishop's "haul," and his description of a beaver dam and some of the places he visited on his 1826 tour, among others - I have focused on two main stretches of narration, the first covering May to July 1826 and the second the months in 1827 during which Cochrane was sailing along the south coast. These selections stand out from other sections of the journal, not just because of the sustained narrative but also because of the historical interest of such relatively detailed accounts of Newfoundland life among the St. John's elite and, then, among the inhabitants of the poverty-stricken outports. Cochrane might not have aspired, like his two cousins, to make his name as a travel writer, but he shows himself as capable as they were of capturing picturesque details or tales of social life.

In particular, the entries from the spring and early summer of 1826 read as a self-contained sentimental romance. Granted, much of the romance takes place between the lines, but Cochrane reveals enough to make clear that over the winter and spring he had fallen in love with Anne Aplin, the wife of a naval 
officer who was staying as Cochrane's long-term guest. Mrs. Aplin, or Annie, or sweet A-, as she became during her months at Government House, was then in her mid-twenties, had been married for around 10 years, and, like Cochrane, was from a distinguished naval family. ${ }^{10}$ She was the mother of two young sons (the elder around six or seven) who had apparently been left behind in England, something that might have been another tie with Cochrane, whose three children were then in Britain as well. There is no indication that she and Cochrane ever met again after she left Newfoundland in July 1826, even though (in what might be either an odd coincidence or another indication of how small and interconnected the inner circles of the British colonial administration could be) her sister was married to Henry Prescott, Cochrane's successor in the governorship.

Yet from April through July of 1826, Mrs. Aplin was Cochrane's main preoccupation. The journal entries that he made immediately after his arrival include details about his social life, but they also touch on matters such as road building, finding employment for the poor, and both formal and informal meetings with municipal or naval officials. By the spring, any such public concerns seem to have evaporated, and from late April on his life appears to have centred on finding chaperones - the daughter of Colonel William Haly or the wife and daughters of his aide-de-camp, John Dunscombe - to enable him to spend as much time as possible with Mrs. Aplin without violating propriety. How far the affair went must remain a matter of speculation, given the discretion, or obliqueness, of Cochrane's phrasing. That said, the repeated, heavily underscored references to encounters being "delightful" or a "disappointment" begin to sound like a form of private code, and Cochrane's frank misery following Mrs. Aplin's departure make clear that it was more than simply playful flirtation. There is also a hint of how much Cochrane might have omitted from his journal in a letter that he received the following spring from Eliza Dunscombe. In it, she notes with some discontent Cochrane's "great change in manner" towards her and her daughters, and rather tactlessly wonders if that change might arise from a needless worry that she might "disclos[e] any thing that may have passed . . . during our visits to the Cottage."11 Cochrane's stiffly worded denial that there was anything he would want to hide is unsurprising, but Mrs. Dunscombe's letter makes clear that not all of his friends would necessarily have agreed with him on that point.

The air of romance is not the only reason that the entries focusing on Mrs. Aplin and Virginia Cottage merit attention; more generally, they underscore the gently anglicized sociability of Cochrane's St. John's. The many references 


\section{Perkins}

to dances, dinners, theatre, and other public entertainments evoke the sort of mild social pleasures described in contemporary English fiction about the provincial middle classes and gentry. It might not be stretching too much to suggest that the flurry of excitement sparked when Cochrane decides to inaugurate his administration by hosting a drawing room has at least some affinities with the world of Jane Austen. Likewise, when Cochrane notes with amusement that "every Milliner" in St. John's "is in requisition" for the party, or when, after an evening of being entertained by the singing and playing of Eliza Dunscombe and her daughters, he reflects rather more sourly that "it is a great misfortune that there are not any musicians among the ladies here" (15 February 1827; this entry is not included in the excerpts), he sounds remarkably like any number of fictional London sophisticates more or less grumpily accommodating themselves to the limitations of provincial society.

Yet if the St. John's that appears in these entries is barely recognizable as the desperately backward, impoverished town of contemporary journalism or even of Cochrane's official correspondence, the entries about the south coast and Burin Peninsula provide a vivid picture of what was, for the current British administration, an almost entirely unknown part of the world. (Even David Buchan, who knew more of Newfoundland than perhaps any other British officer of his generation, was somewhat confused about the Burgeo-Ramea Island area.) Again, one can find echoes of contemporary popular literature in Cochrane's descriptions of the locals: we encounter a somewhat Wordsworthian peasant woman who possesses dignity seemingly beyond her "station"; a weak but well-meaning small-town would-be intellectual; and an impoverished but instinctively pious and inspiring family who would not be out of place in the more sentimental poetry of Thomas Gray or Robert Burns. Even so, this is a world that appears to remain, for Cochrane, almost frighteningly remote, and it is a world that has also remained elusive in literature and history. There are not that many surviving records of the voices of the illiterate and semi-literate fishermen who lived along the south coast of Newfoundland in the 1820s, and in preserving even a few scraps of the lives and views of those people, Cochrane offers a glimpse of a way of life that would have seemed almost as strange then as it does now.

Cochrane's long-term impact on Newfoundland has not been profound. He launched a road-building program; later in his administration, he pushed through the construction of Government House despite all of the controversy about its expense; and, of course, he gave his name to one of the major streets in downtown St. John's. D.W. Prowse, an extravagant admirer of Cochrane 
("universally admitted to have been best Governor ever sent to Newfoundland"), praised him for both the "unbounded" energy with which he set to work and his "unstinted" sociability, ${ }^{12}$ but that reputation does not appear to have survived the nineteenth century. That might be in part because while the journal fully supports Prowse's comments about Cochrane's sociability, the energetic devotion to work is less visible. Hospitality is, of course, an aspect of any colonial administration, but Cochrane's attempt to establish British patterns of elite social exchange in a colony scrambling out of absolute poverty and into representative government might help to explain why what survives in the historical memory of his administration is less the warm good feelings of his arrival than the sour note on which he departed in late 1834, as he and his daughter were jeered and pelted with trash as they walked to their ship down the street bearing his name. Nor does Newfoundland seem to have had any major impact on him. He lived another 38 years after his final departure from the island, and continued an active life of public service that included sitting in Parliament, serving in the East Indies station, fighting piracy in Borneo, and eventually rising to the rank of Commander-in-Chief, Portsmouth. Yet even if the nine years of his governorship were, from Cochrane's perspective, no more than a brief episode in a long and eventful life, the records that he kept of his first two years in Newfoundland demonstrate his initial willingness both to immerse himself in the social life of the island and to explore some of the more remote outports; the result is a work that can offer readers today an unusual view into what is now an almost unknown world.

\section{NOTE ON THE TEXT}

I am very grateful to Maria Castrillo and the National Library of Scotland for permission to transcribe and reprint selections from Manuscripts 2590 and 2591, which include Cochrane's journal between October 1825 and September 1827. I have reproduced Cochrane's text as exactly as possible. In cases where I have not been confident in my reading of a word, I have put it in square brackets with a question mark, or, if I have not been able to make a reasonably confident guess, I have simply indicated the omission with a question mark in brackets. Cochrane often appears to have been writing quickly: he tends to punctuate with dashes and not always to distinguish clearly between his capital and small letters. Where his meaning remains clear, I have left his punctuation as it appears in the original; where necessary for clarity, I have added punctuation 


\section{Perkins}

in square brackets. Likewise, for clarity, I have italicized the names of vessels although in no instances did he underline these. I have also retained (and indicated) passages that Cochrane crossed out or added, and I have expanded his abbreviations, putting the omitted letters in square brackets (e.g., 3[r]d; E[astwar]d; ret[urne]d). Omissions within or between entries are indicated with ellipses, and I have added brief italicized comments summarizing the content of the entries that are not reprinted here.

\section{SELECTIONS FROM THOMAS COCHRANE'S NEWFOUNDLAND JOURNAL}

[Cochrane arrived in Newfoundland in October 1825, after having been appointed to the Governorship earlier that year.]

Tuesday October 11th - on Saturday at two everything being arranged I went in Captain Lockyer's ${ }^{13}$ barge attended by himself and two Lieutenants, with the Union Jack flying in the bow of the boat - after pushing off a Salute of 19 guns was fired - and on the opening out the Grasshopper she was discovered dressed out in flags and immediately fired a Salute - as we approached the shore a very great concourse of people were seen in every avenue leading to and from the landing place, which was lined with the people of the Garrison. The moment I landed I was met by the Chief officers and principal people of the Island. The Batteries fired, the troops saluted, and the populace greeted me with loud and repeated Huzza's. My horses being landed in the morning I mounted my charger dressed out in his accoutrements and attended by the Commandante with the before mentioned persons - with the Band of the 79th and Artillery preceding and the line following, we moved in to Gov[ernmen]t House attended by a large concourse of people and repeated greetings - until we entered the gates of Fort Townshend where I was received by a Captains Guard in [and?] my Commission was immediately read in Gov[ernmen]t House in the presence of many people and then myself and the Council were sworn, on the conclusion of which another salute was fired, the troops presented arms and finished with giving three cheers - The day was very fine and the whole spectacle had a very pretty appearance - and I had every reason to be much gratified with my reception - On Sunday Morning a gazette of the proceedings came out - I attended the went to Church in full uniform attended by Col[onel] Burke ${ }^{14}$ and was most agreeably surprised to find a Church and congregation much surpassing my expectations and as many well dressed 
females as you will meet in many Churches in country Towns in England and a very respectable preacher with good delivery - I was of course the object of curiosity and perhaps brought some there who do not often attend. The Gazette contained a notification that a Levee would be held on Monday and a Drawing room on Monday evening week accordingly - every preparation was made to give dignity to the occasion. A guard with the 79 Band were drawn up in the Court yard the servants were in their state Liveries the heads of the Navy, Military and law assembled at $1 / 2$ past one and at $1 / 2$ past two the outer rooms being filled the doors were thrown open and the Gentlemen advancing singly were presented by the person under whose department they fell and then retired by the opposite doors - [W] had a very respectable assemblage of about 150 who went through the presentation remarkably well - one or two were rather frightened but I believe all were well pleased - I hear that the ladies are all in great glee at the idea of a drawing room and every Milliner is in requisition and I am told the ladies have made a number of fine speeches with respect to me $-[\mathrm{O}] \mathrm{n}$ Sunday and yesterday I rode a little way into the Country and that of yesterday was really very pretty, being up the head of the harbor and along a pretty picturesque valley - with many very excellent fields of grass - and other tolerable cultivation[.] The sides of the hills are very bare, but the grounds lies well and when formerly wooded must have made a fine landscape - I passed through the Town and after having heard it so ill spoken of was much astonished to find so good a street as the main street which must be three fourths of a mile long and contains a quantity of very good shops - excepting Barbados \& Jamaica \& Trinidad it is equal to any other street in the West Indies. Captain Lockyer has staid with me since my landing and the Douglas's ${ }^{15}$ dined with me yesterday and today with the intention of sailing but the wind would not permit them - I however fancy they will be off tomorrow - I am sorry they are going away - I have been so much occupied and the day has been so indifferent that I only walked out for half an hour before dinner -

Thursday October 13th - yesterday morning the Romney sailed with the wind to the North[war]d \& East[war]d - and the weather very cold with a little snow in the morning. Colonel Burke and myself attempted to ride to Windsor Lake but it proved so cold we were glad to return before we got three miles - had a long consultation with the president ${ }^{16}$ on various subjects today the weather is milder and the wind returned to the SW quite adverse to our friends in the Romney [.] [T] ransacted various business today and rode out to the west northward with $\mathrm{Col}[\mathrm{onel}]$ Burke \& Major Skinner ${ }^{17}$ to the north. Observed several spots of very excellent grass - employed getting my things 


\section{Perkins}

brought up from the Town - was visited by the Catholic Bishop ${ }^{18}$ who is well spoken of.

Sunday 16th - on Friday Breakfasted early and accompanied by Col[onel]s Burke, Lewis \& Major Skinner \& Cap[tai]n Paterson ${ }^{19}$ rode over to Portugal Cove for the purpose of examining the road and seeing the place - the first four \& half miles brings you to Windsor Lake the road to which is very rough and stoney but could easily be brought into order and at a moderate expence - as the bottom is hard and there is plenty of ground contiguous to it - it is entirely bare of timber, the whole having been cut down from time to time Windsor lake is very pretty and they say twenty miles round - a small cottage was built by Admiral Pickmore ${ }^{20}$ on the side of it [. F]rom thence skirting only the lake the country is closer with some tolerably tall trees. The road is only passable for a horse and by way of precaution we left our own horses at a cottage in the side of the Pond - and mounted those of the country - some part of the road tolerably well carried until we approached near the cove, where it becomes steep and very rocky - on nearing it we were met by two of the principal fishermen and conducted to their wild, romantic village and received with a flag flying on top of his house and the discharge of three or four musquets - we descended in a cleft between two very high hills and the straggling village with their fish flakes are [sic] built upon the rocky ground of a shallow cove - having in front of it at the distance of three or four miles the Island of Belle Isle and at the distance of fifteen miles the opposite coast of Conception Bay - It contains about 650 inhabitants - has a small Church which serves as a school - [T]hey complained of distress in consequence of not being able to procure credit for their winters supply - I have promised them work upon the roads and on our way back we walked for nearly a mile through a wood that will give a better line of road than part which the old one follows[. A]fter having explored about for some time we returned and reached Gov[ernmen]t House by six oclock when the Gentlemen of the party dined with us - [O]n Sunday morning we set off again with the exception of Col[onel] Lewis to explore a road from hence to a place called Topsail which Major Skinner and some others cut through the wood for the distance of ten or eleven miles and opens out at the before mentioned place about eight miles further up the Bay of Conception than Portugal Cove - to which latter place the fishermen settled along Conception Bay were obliged to go to get to St. John's - but by the present situation they avoid a most difficult and tedious journey there by going straight from Topsail to the Capital and except one or two steep hills that may easily be avoided you have nearly a level all the way $-[\mathrm{T}]$ he road is of course 
miserably bad being formed by merely cutting down trees occupying the width of a path - yet bad as it is seventy head of cattle have found their way to St. John's since last year, a thing that never happened before - and people from the bottom of the Bay came here to purchase their own supplies which before they had to take from the merchant in their neighbourhood at a high rate. We left this before nine and travelling along a tolerably level line through wood all the way until within two miles of the Bay where the path is very steep we reached the water side in four hours \& a half and came out immediately opposite little Belle Isle and the West End of the Great one and saw very distinctly the opposite and bottom of Conception Bay the land about which as well as to the West[war]d of where we were is of a much lower character than about St. John's - met some fishermen who told me the road was a great blessing and that now people were begging [sic] to rear cattle for St. John's market. The day was most beautiful and the coast looked very fine. We rowed a short way upon the water and after having made a little Luncheon again mounted the horses and reached this between six \& seven[,] when Captain Aplin who accompanied me and the rest of the party with the exception of the Colonel who had met with a party [on?] accident dined with me - today went to Church and took the sacrament - had a long conference with the president afterwards and walked with $\mathrm{Mr}$ Brenton $^{21}$ before dinner[;] in the evening read prayer to the family -

Monday 17th - The Drawing room was to have been this Evening but it promised to be so rainy that it was put off until tomorrow - and fortunate it was so for the ladies would immediately have been drenched. Nothing particular occurred today[. W]alked for about an hour — issued a notice offering Employment to those who could not get it elsewhere -

Wednesday 19 - yesterday and today the weather obliged me to put off the ladies from the Drawing room as they could not have failed to have been drenched in coming up - It has been blowing hard from SW all day with drizzling rain[.] Yesterday I received addresses from the inhabitants - Chamber of Commerce and two or three other besides - congratulating me on my arrival - they were received in state with all the officers of Gov[ernmen]t in attendance.

Tuesday Oct 25 th - by some mistake or other forgot for some days to write my journal - Nothing however very particular has occurred since last doing so - except the Drawing room which intending to be held at yesterday week was in consequence of bad weather postponed from day to day till Friday when it took place at 8 in the evening. Such a thing never having before occurred in $\mathrm{N}[\mathrm{ew}] \mathrm{f}[$ ound]land it had excited a great agitation among the 


\section{Perkins}

ladies who had been since the intimation [invitation?] was given out constantly employed in preparations for the occasion, which many looked to with considerable nervousness - the two public rooms were prepared with benches round them and the Billiard room for them to arrange their dresses in \&c \&c - as the seats would only be sufficient for ladies the gentlemen were to stand behind them - $[\mathrm{A}]$ ccordingly about eight they began to assemble, Mr Brenton and two Colonial Aides de Camp arranging them in their places. When all was ready he reported to me who was in waiting with the council judges [\&c?] in another room. On entering - the ladies rose and I having proceeded to the head of the room and first presented myself to Mrs Tucker ${ }^{22}$ and then accompanied by the chief justice went round to every lady whom he presented to me and I shook hands with her - the presentation of the last lady brought me to the head of the room again where the Gentlemen were allowed to come from their stations and we all mixed in assembly and after staying about half an hour they went away - the servants were in full livery $\& c-[\mathrm{O}]$ n Saturday the [Pelter? ${ }^{23}$ sailed for Halifax. Sunday went to Church attended by one of my Colonial aides de Camp. The weather cold and blew strong from the N \& E[astwar]d Monday, a very unpleasant rainy day. Captain \& Mrs Paterson dined with me - [T] oday after having looked not for her for some time the yacht ${ }^{24}$ made her appearance having left Plymouth on the 27th Sept[embe]r, bringing me one or two letters and thank God satisfactory or at least not unsatisfactory accounts of my dear father. The Captain of the vessel not come onshore. -

Wednesday Oct 26 - Captain Morice ${ }^{25}$ came on shore at Breakfast from whom I find he has had constant gales all the way out - I am sorry to say he was obliged to leave my Coxswain Smith behind in consequence of bad health - The [crew?] consists of 7 but I fear not very good - rode out accompanied by the Col[onel,] Major Skinner and Captain Aplin to Torbay[,] a distance of about 7 miles wretched road[. P]opulation about 500 - miserably off - Catholics and protestants divided by a river - the latter just built a small Church to which they mean to add a store - met with several showers of hail on the way and the day cold - got home a little before six -

Friday Oct 28 Yesterday most distressing accounts came by the Halifax mail of a most dreadful fire having taken place at Merimachi, destroying eighty miles of country with all the Towns and Villages that came in the way - It must have been beyond anything terrific - many two hundred people were known to have perished when the accounts came away but it is much feared the extent of lives lost was by no means known. The water of the River was so hot that fish were found destroyed on the Beach - almost all the provisions in 
store were burnt - and people were wandering about naked, homeless, and famishing - at Halifax they have raised a handsome subscription for their relief and one is already begun here which I hope may prove successful - today received three addresses and afterwards rode out to survey the improvements going on.

Saturday 29th — It blew very hard last night — but moderated towards the morning - the weather has been very warm. It rained all the forenoon but cleared up towards the Evening and the Sun set beautifully — rode before dinner to Windsor Lake -

Sunday 30th - a fine day - went to Church as usual but fear I did not receive much benefit from it - after Church had a consultation with two Gentlemen of the Town on the subject of the relieve [sic] to be sent to Miramichi - then accompanied by Mr Brenton and Major Skinner walked to the entrance of Kidy Vidy which is very wild and Romantic and the view of the opposite side of the lake on the way there was very picturesque - the village of Kidy Vidy small and miserable[,] the entrance to the little Bay commanded by a four gun Battery -

[During November, Cochrane started spending more time around Dowland's Pond, which he renamed Virginia Water, and set out to improve the road there and to repair and furnish the lakeside cottage that he noticed on his first visit, work that he continued, combining it with social outings, into December.]

Wednesday 23rd Monday morning very rainy, but, clearing up towards the afternoon went accompanied by Col[onel]s Lewis \& Hayley ${ }^{26}$ to inspect a new line of road proposed by the latter but which on examination did not offer any advantage of importance over the line intended to be adopted — and made a much greater distance - yesterday the weather fine - a party at dinner when the Cook again behaved very ill and it now turns out that he is a Drunkard and I fear has been some time so - he has made today many faithful promises of amendment which I much fear are not likely to be realized. Some snow fell in the night - accompanied by frost which has made the roads very slippery today.

Saturday 26 - on Thursday rode out to where the line of road is altering to Windsor lake - and found them getting on very well with it and a very pretty line of direction will shortly be substituted for what is now Bleak and dreary - yesterday I walked to Virginia water where operations are also going on but not so rapidly - in the Evening had a large party at dinner which the latter went off tolerably well and so far the Cook has kept his word - today 


\section{Perkins}

went to mark out the sight [sic] for the new house and then surveyed the various improvements going on in the Town - which has had more done to it within the last six weeks than in the previous Two years. -

Monday 28th - yesterday was most delightful and but for the snow upon the ground or rather the ice - I could scarcely have persuaded myself that this was the month of November. I walked after Church to Virginia water $-\mathrm{Mr}$ Carrington the clergyman dined with me - and in the Evening he read a sermon to us and the servants[. T] oday has been mild and cloudy - drove in the Phaeton through the Town and then rode to Waterford Bridge where a new Bridge is about to be erected[.]

Sunday Dec[embe]r 4 with the Exception of one or two days last week has been very fine and various operations on the road have been in progress had a party of twenty at dinner on Friday eight of them Ladies. There is nothing particularly new to mention[. T] he last arrival from England brings no intelligence[. T] oday went to Church as usual and in the Evening read a Sermon to the servants.

Monday Dec[embe]r 5 - Rode out accompanied by Colonel Lewis to lay out a new line of road towards Virginia water so as to avoid the hill at Col[onel] Hayleys [sic] It was very unpleasant and snowed a good deal when we first went out - but afterwards cleared up and we rode through the town to Waterford Bridge - very considerable improvements going on at the West End of the Town - a small party dined with me - intended going to see Major Skinners improvements on the Portugal Cove rode $[$ sic] today but he was taken so unwell yesterday as to make it imprudent for him to go out today - rode today to Virginia water[. T] here has been a little slaying [sic] today altho there is not much snow on the ground -

Thursday Dec[embe]r 8th - rode out on Tuesday to see the Progress on the Virginia Water road - and yesterday walked towards Windsor Lake[.] Had a Party at dinner yesterday - it snowed last night[;] today went in $\mathrm{Col}[$ onel] Hayleys sleigh to Virginia Water but the snow was not deep enough to make it pleasant - called at the Col[onel's] on the way back -

Saturday Dec[embe]r 10 Yesterday morning a party of gentlemen Breakfasted with me and then accompanied me to Portugal Cove for the purpose of seeing Major Skinners new road. Some went in sleighs but the snow was not sufficiently deep to make that mode of travelling agreeable - we descended to the Cove by the Major's new cut - called Goffs Lane after a decent old man who keeps a sort of Inn at the Cove and has been active in making the Road[. T] he line of direction is far better than the old one. That part of the road is 
only framed but from thence to the cove the road is as fine as any in England - we remained there to lunch and I reached Gov[ernmen]t house a little after four - a small party dined with me - last night it blew a gale from the S/E and the snow is now nearly all gone[. R]ode to Virginia water laid out some walks and walked back.

[During the following two weeks, Cochrane noted mainly the bad weather and more rides out to inspect the roads.]

Thursday Ev[enin]g Dec 22 - Since Sunday a thaw has come and nearly the whole of the snow disappeared - this Evening it is freezing a little - I am still employed with the roads in all directions. Yesterday the usual party at dinner of 16 - now just returned from the Amateur Theatre - which is as neatly fitted up as any thing of that kind that I have at any time seen indeed with more taste than most provincial Theatres in England and the performance was really very tolerable. The worst part in all these cases is the lady, which being performed by a gentleman is rather outré. There was one gentleman named [Ingall?] who acted the ladies part very fairly - The play was the Mountaineers and the after piece Three Weeks after Marriage. ${ }^{27}$ It was very well attended but the greater proportion were men.

[There are three more December entries, consisting mainly of complaints about bad weather.]

Friday January sixth 1826 Quite astonished on opening my journal to find it a week behind not that I have much to put in it - New Years day was wet and disagreeable and since then until yesterday it has been constant open weather so as to carry off all the ice and snow - and injure fish [\&c?] that I had packed in Ice to preserve it - the Thermometer some times stood at 54. It is now freezing hard - I have been anxious to get rid of the employment of the poor and hope the coming weather will enable me to do so - yesterday sixteen men of one party who were discharged met me and said they had not the means of buying food for the day or procure lodging for the night - I was obliged to continue them on -

Friday January 20th. This last fortnight has been made up of most extraordinary weather, the Thermometer standing for a great part of the time above freezing and the Bar[omete]r above 30. There has been a heavy fall of snow but the greater part of which has disappeared and the roads in a miserable state being neither fit for sleighing nor driving. This state of the weather has also pressed hard upon the lower orders incapacitating them from going into the 


\section{Perkins}

woods to cut timber - which has thrown a great number upon my hands for whom I have been obliged to find employment -

Today I hope I accomplished the important object of getting the people agreed upon the subject of a Corporation for the Town. Some of their principal advisors and leaders were with me and have concurred with me on the basis on which it is to be established and which they are to submit to their fellow Townsmen - last evening I had my second evening party which went off very well and was all over by twelve o'clock.

Sunday January 29 - The incidents that occur are so little worthy of notice that I have allowed my Journal to fall into arrears - the weather has been very uncertain but on the whole more decidedly winter than before - the sleighing being good and the ponds well frozen - the last vessel this season for England either sailed this evening or goes tomorrow morning henceforth till May there will not probably be any direct opportunity but occasionally by the circuitous route of Portugal.

Friday February 3rd - on Tuesday night I went to the play and in consequence of the snow drifts that came on had some difficulty in getting home again. On Wednesday it blew extremely hard and was bitter cold. I paid a visit on board the Grasshopper to see Captain and Mrs Aplin ${ }^{28}$ who have been very unwell, and to persuade them to come and stay with me at Gov[ernmen]t House. The same day I had a dinner party when Col[onel] Burke was frost bitten on coming up and on Wednesday night the cold was so excessive I was unable to sit in my little study. The thermometer was I am told as low as 8 below zero but it was the violence of the wind that made the cold so piercing. It is said that for seven years there has not been such a day - yesterday the wind went down and the weather became fine - I walked to Virginia water - in the evening had a soiree - To day mild and dull weather - called on board Grasshopper - the Aplins come to me on Wednesday[.]

[The entries for the rest of February are concerned mainly with the bad weather and with sleighing excursions that Cochrane made with Captain and Mrs. Aplin to Virginia Cottage. He also noted his first sight of an iceberg and the departure and return of the sealers "with a very good catch of seals[,] one of them having taken three bears" (5 April). By March, Cochrane had settled into a routine of outings to Virginia Cottage by day, following by reading to Mrs. Aplin, playing billiards, and dancing in the evening, varied by visits to the theatre or an occasional private concert. His entry for $27 \mathrm{April}$, describing a celebration the previous day to mark the first anniversary of his appointment to the governorship, makes 
clear his increasing fascination with Mrs. Aplin.]

Thursday April 27th - yesterday being the day that appointed first [sic] we had the Salute - Levee, drawing room and Ball[,] all of which went off well notwithstanding the conduct of my worthless Cook, who has been drunk for the last four days[. W] e mustered in the Ballroom about 100. Annie looked beautiful - I passed the greater part of the Evening delightfully with her and the only danced [sic] I danced was with her - we broke up between three and four and I went to bed but not to sleep. The Remembrance of how soon my pleasures are to terminate - deprived me of all happiness - I passed a wretched night[. W] e breakfasted at Ten[. P] assed the forenoon below[. A]fter Luncheon we drove out to Bally Haly and took Mrs Tucker to Virginia Cottage — dined alone that is our own party.

[Unsurprisingly, Captain Aplin was growing increasingly discontented and eager to leave: in his 22 April entry, Cochrane records that it had taken "quite an altercation with Aplin" to persuade him "to stay with me until the day before he goes to sea"; on the 28th, Cochrane writes that he has "set Engines to work to see and persuade him to post-pone his departure." During May and June, Mrs. Aplin becomes the focus of the journal.]

Monday May first Very fine day. Spent a most agreeable forenoon - and after luncheon drove out with Miss Haly ${ }^{29}$ with us - went to Virginia Cottage then drove to Riverhead - had a small party at dinner and danced a Quadrille.

Tuesday May $2[\mathrm{n}] \mathrm{d}$ - The day has been tolerably fine - after luncheon we drove to Virginia Cottage - the Superintendance of which Col[onel] Lewis has given up - On returning I read to Mrs A (who had not been very well all day) until five o'clock when we dressed to dine at five and at 7 o'clock we went to the play - I had a large party of ladies in my box. We reach'd home again by $1 / 2$ past 11 .

Wednesday May 3[r]d In the morning cloudy but turned out a fine day tho cold - Miss Haly came in the forenoon and after luncheon she drove with us and we then left her at home. Play'd at billiards in returning home - had a party at dinner — and danced with $\mathrm{S}-\mathrm{t}[$ sic $] \mathrm{A}$. in the evening. -

Sunday May 7th On Thursday nothing particular happened. On Friday a fine day. Miss Haly came. Was much distressed some time in the forenoon but it soon passed off and passed a most agreeable morning. After luncheon Miss Haly drove with us - went to Virginia Cottage[,] staid some time sitting over the fire then ret[urne]d home. On Saturday Miss H came and passed the day with us spent a delightful morning - After luncheon called at the Dunscombes ${ }^{30}$ 


\section{Perkins}

to look at a stove then drove to the Cottage and sat there some time. Read to the ladies before dinner. Had a party at dinner - and danced with Mrs A - in the evening - The day very fine - Today went to Church. Rained on returning - drove out before dinner - In the evening had prayers \&c and afterwards read a little -

Monday May 8 - We had a fog until 3 oclock when it cleared up a little. Miss Haly spent the Forenoon with A'e [sic] and after Luncheon drove out with us and we put her home. Cap[tain] $-\&[s i c]$ did not go out. During the forenoon sweet A play'd for me before dinner - Had a party at dinner and danced 3 quadrilles in the evening.

Tuesday May 9th The first part of the day very fine but latterly foggy - the wind still to the eastward so as to prevent the yacht sailing with the judges. Yesterday two arrivals from England bringing papers to the 10 April - after luncheon drove out with Mrs A - made a call at Col[onel] Burke's and she at Mrs Lewis, then went to Virginia water. On the way back called at the new garden. Dear A-e sang to me before dinner, in the evening we read and play'd billiards[.]

Friday May 12th - on Wednesday it rained all day - Miss Haly came to us after Breakfast and her mother came to dinner, by which time the weather became so bad some of our party did not come and by eleven oclock it snow'd and drifted so hard that Mrs \& Miss Haly were obliged to remain all night and on Thursday morning we found there had been a very heavy fall of snow and it continued snowing \& thawing all day. The ladies went home at ten in their sleigh and in the afternoon we took a short turn in the sleigh in spite of it then snowing that we might say we had done so on the 11th May. We had no company in at dinner - in the evening Mrs A practised the guitar and we play'd billiards - Today commenced remarkably fine and at five in the morning the yacht sailed with the judges - After luncheon we drove to Virginia Cottage calling at Baly Haly to ask the Tuckers to dinner tomorrow and [?] Miss $\mathrm{H}$ to pass the day - Several vessels came in and signals for others were up all day - and while at dinner with a small party a Man of War was announced as being off and before we rose from the table Captain Canning ${ }^{31}$ came in, having arrived in the Orestes to take command of the Grasshopper - This has put us in a good deal of agitation, as $\mathrm{I}$ we are ignorant of what his plans are to be altho I hope yet to keep him here for some time - but more of this tomorrow - in the mean time as he wants to call on Cap[tain] Litchfield tomorrow morning we have been obliged to send for Miss $\mathrm{H}$ to come to breakfast otherwise she would have been compelled to go also. ${ }^{32}$ 
Saturday May 13th — after breakfast Captain Aplin went [on board with?] Capt[ain] Litchfield. Miss Haly staying with Mrs Aplin, we passed our time very pleasantly till he returned bringing Capt[ain] Canning with him - a small party at dinner, Capt[ain] Canning one of them - It is I believe now settled that the Aplins will go home from hence in my yacht when she returns from Halifax It has rained hard today we could not go [over?] town

Monday May 15th Yesterday was a rainy forenoon - the Aplins went onboard to pack up their things - and returned to luncheon, after which the weather clearing up we took a drive. Capt[ain] Canning and Major Skinner dined with me. In the evening I was much annoyed - but this morning it was all removed - they went outward again and finished the packing - After Luncheon we went to Virginia water, calling on the Tuckers at Baly Haly en chemin. A small party at dinner in the evening, danced two quadrilles - Cap$\mathrm{t}$ [ain] Litchfield called today.

Wednesday May 17th Yesterday Miss Haly came to us and after luncheon we went in the carriage and first drove to River head and then to Virginia Cottage for the purpose of fishing but found it rather too cold to attempt it. Had a small party at dinner - today Miss $\mathrm{H}$ came again, but it was of no use - after luncheon we went to Virginia Water and got into a boat and fish'd on it for an hour when Mrs Aplin caught three small trout - Returned home before six oclock and cozed over the fire till dressing time. Was put much out of spirits while out - A large party in the at dinner - danced a Quadrille with Mrs. A. in the evening -

Thursday May 18th - Intended going in the yacht to take a sail today with Mrs Aplin and Miss Haly when it came on to blow so strong we were obliged to give it up and instead take a drive and then went to Virginia Cottage and went through the walks where Mrs A had not been before. Put Miss $\mathrm{H}$ down on the way back - Captains Litchfield and Canning dined with me - Play'd billiards in the evening -

Saturday May 1920 Yesterday appearing fine we went on board the yacht and sailed up and down the Harbor where in spite of the water being as smooth as a pond — she felt sick - The wind was tolerably fresh. We continued under sail for about $3 / 4$ of an hour and then anchored — Capt[ain] Canning \& Miss Haly were of our party - On landing we drove Miss $\mathrm{H}$ to Baly haly and there but first went to Gov[ernmen]t House to make up some letters for Halifax and then drove to River head - Dined alone. In the evening music \& billiards - the Grasshopper and Forte sailed about five o'clock - Today fine but cold. Drove to Virginia water and then fish'd but had no sport - A dinner party and in the evening they were sang, billiards play'd billiards those who are a match for each other 
Wednesday May 24 - On Sunday we went to Church and afterwards drove out to Virginia water returning home in time for dinner - On Monday morning Miss Haly came to us - Capt[ain] A went out for the forenoon to pay a visit to Col[onel] Burke - Passed a delightful morning. After luncheon went to Virginia water. Miss H returned with us to dinner - A small party. Play'd billiards and danced Quadrilles - one with Mrs Tucker one Mrs A - Yesterday called on Col[onel] Burke. After lunch went to Virginia water and fish'd but caught very few - nobody at dinner - in the evening read to Mrs A met with a [?] — today beautiful. Mrs $\mathrm{H}$ came to us. Passed a delightful half hour this forenoon. After Lunch we went to the Cottage and fish'd but with very bad luck. Afterwards carried Miss $\mathrm{H}$ home - Had a large party at dinner.

Thursday May 25 In the forenoon the wind shifted from the Eastward to the $\mathrm{N} \mathrm{W}$ with a good deal of rain and thunder \& lightning for two or three hours - but wind round to the N[orthwar]d \& E[astwar]d again and continued foggy and disagreeable all day - We drove to see a wherry that I have the intention of buying to place on Virginia water and afterward drove to the waterfall leading to the water - Dined alone. In the evening Mrs. Aplin sang and play'd to me - and after tea we play'd a little at billiards.

Saturday May 27th Yesterday a very fine day - Miss Haly came to us in the morning - spent a delightful forenoon. After luncheon we drove to River head then to Virginia Cottage and rowed about upon the water in a pretty wherry I had just purchased. On our way back left Miss $\mathrm{H}$ at home - Dined alone - Today foggy and rainy - met with a disappointment in the morning and have been much annoyed the greater part of the day - drove out in the rain - to Baly haly and took up Miss $\mathrm{H}$ then went to Virginia water - but were obliged to remain in the house as it rained constantly - Miss $\mathrm{H}$ returned to dine with us and was joined by her Father and Mother and a small party -

Monday May 29 - Rained in the morning yesterday. Went to Church in the carriage and after luncheon being drove $[$ sic $]$ to Virginia Cottage, taking up Mrs Haly in the way - We were afterwards joined by her Daughters \&c on horseback and went on the water in the wherry - In the evening Mrs Aplin was very unwell with a severe head ache and did not come down to coffee This morning she was well again - and as I suspected had been annoyed Miss Haly came after breakfast. Spent a delightful forenoon. Went out after luncheon to Virginia Cottage. The weather had been delightful all the morning but became overcast and [began?] a drizzling rain by the time we got there. On our way back called at Baly Haly and invited the Tuckers to dinner tomorrow. On our return home read to Mrs A before dinner - 
Tuesday May 30th — Still a strong easterly fog through which the sun in vain attempted to penetrate today - Called on Col[onel] Burke and sat with him some time after luncheon went to the Cottage but the weather was too raw to go on the water - On returning read to A - until dinner time. $\mathrm{Ch}$ [ief] Justice, Mrs Tucker \& small party dined here -

Wednesday May 31 - A very rainy morning - until near noon when the wind came to the W[estwar]d and it cleared up - Miss Haly came this forenoon and I hoped we should have spent a pleasant forenoon but was disappointed Called on Col[onel] Burke. After luncheon we drove first to the ordnance yard to look at some marble chimney pieces then to the lake to fish - but it blew rather strong - Mrs Aplin caught three - Dined alone. Mrs A sang to me and we play'd billiards after tea -

Friday June two - Yesterday we determined to dine in the Cottage and accordingly sent every thing necessary out and went at three oclock to fish all the afternoon but and called at Baly haly to take Miss $\mathrm{H}$ in - and were followed afterwards by $\mathrm{Col}[$ onel] \& Mrs Haly \& Mrs Tucker - we went on the water to fish but found it so cold and blowy that Mrs A was obliged to give it up and about six o'clock it provokingly became showery - The children came out with $\mathrm{us}^{33}$ - we returned home about ten oclock and had a fine evening - the drive to me was delightful - Today we drove to the Cottage but it was too raw and cold to venture on the water. We therefore walked round the peninsula Read to Mrs A on returning - A small party at dinner -

Saturday June 4th - on Friday E[venin]g invited the Dunscombes to dine at Virginia Cottage[. Y] esterday during the forenoon it rained part of the time and looked very doubtful all day we however set off at $1 / 2$ p [as]t 3 taking the chance of the weather and shortly after our arrival were joined by the Dunscombe's and then walked about the grounds - dined at $1 / 2 \mathrm{p}$ [as]t 6 and returned home between $9 \& 10$ having had but little rain during our departure - today the weather was finer but much colder[. W]e went to Church and after Luncheon drove to the Cottage - walked about and then ret[urne]d -

Wednesday June 7th - on Thursday raw easterly wind. Went to the Cottage as usual - a small party at dinner where some of them danced in the evening - Yesterday spent a most wretched day - went to the Cottage. Could not appear at dinner - In the evening better - today quite myself again - The day remarkably fine. Went to the Cottage to dine[;] our party joined by the Dunscombes and Major Skinner. Mrs A and the ladies first employed themselves in planting a border with flowers then went all the party sailing and fishing until near seven - when we dined and left the 
Cottage about $1 / 2$ past nine - Had a most delightful drive back and then play'd Billiards -

Friday June 9th - Yesterday intended going early to spend the day at the Cottage to be joined by the Dunscombs but the weather put on such a threatening appearance that we postponed it till after luncheon, when we met the Dunscombs returning from the Cottage, supposing we had given up coming. They turned back with us - the children were with us - Employed ourselves cleaning and planting the borders - for which the day turned out better than I expected. We dined about 7 and after tea between nine and ten we left the Cottage and had a most delightful drive home - Today the weather was raw and cold but we went to the Cottage for an hour, the children with us - in the evening A - play'd and sang, and after tea we play'd billiards[.]

Sunday June 11th - Yesterday at eleven we went to Virginia Cottage and before luncheon were joined by the Dunscombs - the day was delightful and we were all employed gardening - sweet A-e directing every thing that was to be done - We lunched under the Trees - Judge Desbarres ${ }^{34}$ and $\mathrm{Mr}$ Brenton joined us at dinner. We dined at 7 oclock and returned home between $9 \& 10$ - Today went to Church - The weather has been threatening - with the wind SW - After Lunch drove to the Cottage for a short time - The Orestes has arrived - In the evening after prayers - A-e play'd and sang.

Tuesday June 13th - Intended dining at the Cottage and the Dunscomb's with us yesterday but as we got part of the way there it came on and continued to rain so hard that they did not come - We were confined to the house and Annie worked while I read to her - Col[onel] Lewis joined us before dinner and we returned to Town between $9 \& 10$ - without rain - The Orestes came in the evening before and Captain Litchfield was to have joined our party but for the weather - This morning we had an alarm at breakfast of the yacht being off. I could scarcely believe it possible that such was the case yet they made that signal and the signal man came down and declared it to be the case There was therefore little room left for doubt - and for a couple of hours I partly believed it until the vessel standing in, it was found to be a mistake - At one oclock we went out to the Cottage and overtook the Dunscombes who afterwards joined us there. The day was fine and dear A[-]e employed herself all day out of doors - in laying out Walks \&c\&c - In consequence of an accident happening to the D's gig we did not leave the Cottage till near ten - the children were with us - Cap[tain] A took it into his head to walk into St John's and out again -

Wednesday June 14th - a very fine day. Lunched early and drove to the 
Cottage — while there Miss Haly p[ai]d us a visit and she[,] A-e and myself rambled about in the wood for birds nests. Dear A- superintended the improvements also. We came away at $1 / 2$ past five and had not got far before a swingle tree bar $^{35}$ broke and we had to get rope from the Cottage to repair our damage and go on - Cap[tain] A. seems very discontented - and tired of going to the Cottage - We dined alone. In the evening play'd billiards - During dinner had another false alarm of the Forte being off - a vessel came in from Halifax today, leaving her there -

Thursday June 15th, a brig arrived this morning from Halifax with the May mail - a letter came by her from Thomas mentioning he would sail about the 10th - A fine day. Drove with sweet A-e to the Cottage, staid a couple of hours and returned to a small party at dinner, and one or two came in the evening -

Saturday June 17th - Yesterday we were to have passed the day at the Cottage with the Dunscombes but it turned out so bad we were obliged to give it up and I after playing a little at billiards - Today turned out but very little better. We however set off taking our provender with us and had not gone far before the weather appeared so doubtful we returned and put out the dinner and then drove over with the intention of returning again to dine, but when we reached the Cottage we found the Dunscombes there; we sent back for the dinner and dined at 7 o'clock. We found within pleasanter than without of these raw days. Before dinner I read to the ladies - we left the Cottage again a little after nine and got home about ten or past -

Sunday June 18th - The yacht came in this morning from Halifax - it makes me melancholy to see her as she is so soon to rob me of one I dearly love - my heart bleeds when I think of it - We went to Church - afterwards Capt[ain] Litchfield who is posted and his successor who came in the yacht called on $\mathrm{me}^{36}$ - After luncheon drove to the Cottage taking Capt[ain] Morice with us. Cap[tain] A. much out of humour - read to sweet A before dinner. After coffee had prayers and in the evening sang she play'd and we sang -

Monday June 19th - A bad unpleasant day - dearest A at work as usual for me all day - after luncheon I read to her little - We then went to the Cottage and in returning read to her again till dinner time - We took Morice to the Cottage to shew him what sketches to take of it. In the evening she play'd and sang and then we play'd Billiards. - A. better today than yesterday.

Thursday June 22 - Tuesday was a cloudy day - after luncheon went to the Cottage. Met Capt[ain] Morice coming from thence, he having been sketching. Staid a short time and returned. Read to her before dinner. In the 


\section{Perkins}

evening she sang \& play'd afterwards at dinner - Yesterday remarkably fine - Lunched early and then went to the Cottage. Shortly after was joined by Mrs Dunscombe and young Ladies - and before dinner Capt[ain] [Jones?], Morice, and $\mathrm{Mr}$ Clarke came out - A and I laid out a new walk together, also prepared some ground for plants - she worked till $1 / 2$ past 6 - every moment indoors she dedicates to my use in preparing curtains \&c. for my rooms - Left the Cottage at $1 / 2$ past nine. The moon had just risen and was beautiful - Today we have had another remarkably fine day - after breakfast [dearest?] A. occupied herself with my curtains till noon when we went to the Cottage and were shortly after joined by the Dunscomb ladies - when they all worked during the greater part of the day till dinner time. Col[onel] Burke came out to visit us - we lunched under the trees - [Captain] A. is sulky as a bear and will do neither one thing or another. The rooms are getting on quickly, the two bedrooms papering - he has been at her to pack up and in short wants to do anything to prevent her going to the Cottage. $\mathrm{Mr} \mathrm{Carter}{ }^{37}$ dined with us - we remained till past nine then returned home and play'd billiards. Were it not for the recollection how soon we are to part, I could be quite happy - but that day approaches too fast to admit of it. -

Friday June $23[\mathrm{r}] \mathrm{d}$ - a fine summers day, almost too fine to last. We went to the Cottage about noon and afterwards were joined by Mrs \& Miss Dunscomb, Capt[ain] Buchan, ${ }^{38} \mathrm{Col}[\mathrm{onel}] \mathrm{s}$ Burke \& Lewis - After luncheon, wonderful to relate, Aplin went into town to bring out Miss M. Dunscomb. Before dinner our party was increased by Morice, the chief Justice \& Brenton. They went upon the water in the boats - I went for a short time - during the rest of the day was with sweet A either reading to her $\&$ then working - or gardening - we dined after seven and left the cottage at $1 / 4$ before ten.

Sunday June 25 th - Yesterday was a remarkably fine day $-\mathrm{A}$. had been so long on the fidgets about his going that I was this morning obliged to decide it and accordingly sent for him before [?] and told him that we should be ready for him on Thursday or Friday - whether pleased or not I cannot say - but to me it is most painful to have to fix the time of their leaving me. - I find that reports have for some time been going about of my intention of sending the yacht home - which there is no doubt arose from A. not being able to hold his tongue - At 11 oclock we set out of the cottage. It was very warm. [Mr Holbrooke?] p[ai]d us a visit before we had been long there - after the Dunscombs came we lunched on the green plot from whence some walks diverge - a very rural spot. Got a swing up for sweet A. - The ladies employed all day at my curtains - Capt[ain] [?] joined our party at dinner - returned home at 
$1 / 2$ past nine - Today an easterly haze - but towards midday it cleared up altho the air is much colder than yesterday - went to Church. After, Miss Haly came to luncheon, after which we took her to the Cottage and then home to Bally Haly, where we got out to see some [apparatus?] of a [french?] bed ${ }^{39}$ - Dear A amused herself before dinner as well as in the evening with drawing - had prayers in the evening[.]

Monday June 26th - The morning promised fine and we set off for the Cottage a little after eleven and found the Dunscombs arrived just before us. It began to rain a little as we got there and continued for an hour when it cleared up quite fine - Dearest A was much affected in the way out, which he observed and put him quite out of sorts - nothing pleased him and he set off for Town with a young Gentleman who had just come out - and did not return until a little before dinner. During his absence I read to the ladies. The band who I had ordered out also play'd, and it was delightful the sound of music among the trees. We then went on the lake and sailed about while the music play'd. A Mr Tobin and [Mr Brooking? ${ }^{40} \&$ Major Skinner dined with us. In the evening it came on to pour and rained all the way home - A was still out of sorts and refused to come down to play billiards on pretence of being wet - and now another day of happiness is gone.

Tuesday June 27th - part of the day was fine, part foggy. Went to the cottage between eleven and twelve. We lunched under the trees, after which A rode into town [\&c.?] with Col[onel] Lewis. During part of the afternoon the ladies worked and then we went to cut out a new walk - the band play'd during part of the afternoon as they did yesterday. Judge Desbarres and Capt[ain] Morice dined with us - it was near eleven when we got home.

Wednesday June 28th - The morning sultry — went out before noon and met the Dunscombs as usual - it shortly after threatened rain and rained a little during the afternoon and evening - there was a terrible explosion in consequence of dearest A. assisting me in putting up some curtains. Mrs D afterwards interposed - and I think he feels a little awkward about it - Judge Carter was to have dined with us but the appearance of rain frightened him away - alas how few days have I now left of pleasure.

Wednesday Ju Thursday June 29th A fine morning and very warm to my surprise A was up before even they] [blank] The As employed all the forenoon packing up. After luncheon we went to the cottage and found judge Carter there - who I forgot I had invited early — which was annoying as I could not give up my time to entertain him - A ret[urne]d to Town on business - during which time had a melancholy walk with _- in the shrubbery. The ladies 
all at work - sweet A- put up my french [bed top?] in which she took the greatest interest - and made it very handsome. Judge Carter \& Capt[ain] Morice dined with us ret[urne]d home a little before eleven -

Friday June 30 - The Aplins packing up till noon then went and paid their visits. At 3 o'clock we went out to the Cottage. Aplin was to have returned to Town on horseback but it was too late. She employed herself until dinner time in pulling up trees and putting the eastern vista to rights. Col[onel] Burke \& Major Skinner dined with - us - the Dunscombs of course - we returned home a little before eleven then play'd billiards -

Saturday July 1st Another fine day and very warm. Sweet A. went out before luncheon to finish her visits and after luncheon, a little after two, we went out and found the Dunscombs arrived. We were to have met at luncheon there but we were detained. She employed herself putting up the curtains and drapery for the bow window in the drawing room - Afterwards she superintended putting in plants in the ground cleared yesterday - He was to have ridden back to town but found it too warm - After dinner it was purposed to walk a little and we all went out, and unfortunately Mrs A Miss D and I for fun ran on from the others so as to perplex them in finding us among the walks. This it appears excited the Green Eyed Monster in him and he found fault with her and a terrible scene was produced which kept us there till eleven oclock and I fear has made her resolve not to go out again there tomorrow - In the evening they embark - and leave me - to solitude \& unhappiness.

Sunday Ju Monday July 3[r]d Yesterday was a very warm day. After breakfast Capt[ain] A went to the Yacht to arrange his things and Mrs A remained to pack up - we arranged to lunch at the Cottage and accordingly drove out there about one o'clock, shortly after Mrs Dunscomb arrived and Mr [?] being there sweet A. finished putting up the curtains. After luncheon Aplin rode into Town to pay two visits - had a last best walk with her through the grounds never shall I forget it - Mrs Dunscomb ret[urne]d to town on his coming back - She finished a drawing of her Cottage at Torquay for me[. W]e then sauntered through the grounds - and at last a little after seven bade adieu to that sweet place - It was eight before we reached Gov[ernmen]t House and nearer nine before we sat down to a melancholy dinner - she wept much[. Some?] of us - scarcely spoke - The time lingered on in preparation for and ahead of departing. At last everything was ready. Eleven o'clock arrived and the carriage was ordered. I accompanied them down and onboard their things were all in confusion, and it was near two oclock before everything was arranged. At last all was ready - and I on the point of bidding a long - long farewell 
when Captain A - asked me to detain the yacht as she was taken ill - I suggested the propriety of sending for Doctor Carson. ${ }^{41}$ The boat that was to have taken me onshore went for him - he came and pronounced that she had a threatening of miscarriage and must not at all events then proceed - I will not describe my feelings - Dr Carson and I ret[urne]d on shore in the same boat - it was past day light before I got to bed but not to sleep. - After breakfast to-day about ten o'clock I went on board accompanied by Doctor Carson She was upon deck. I will not describe or say all I felt - He recommended she should return on shore for a day or two - It was a hard battle for me to get A. to consent and I believe had I not staid and seen them out of the vessel they would not have landed - They came onshore with me. Mrs Dunscomb came and passed the day with her - and will come again tomorrow.

Tuesday July 4th - Doctor Carson came today and I fear has held out some expectations of their being able to go tomorrow - Mrs \& Miss Dunscomb came after luncheon and I read to them, after which Capt A and I rode to Virginia Cottage where I picked A nosegay and brought it to her. The Ds dined with us - the day has been very warm.

Wednesday July 5th - Doctor Carson came about ten o'clock and pronounced that dearest A might go, and she would have been off by this evening, but the wind came in from the sea and there is now every appearance of an easterly wind. It has been very tantalizing all day not knowing from hour to hour whether they were to be off. Mrs Dunscomb and afterwards Miss D came to us and remained the day. - I read to them.

Thursday July 6 - I found the wind to the North[war]d \& East[war]d in the morning with thick fog which turned in the forenoon to rain and continued all day till about 7 oclock when it threatened to come to the N W. I read all day to sweet $\mathrm{A}$ - and he did nothing but pace up and down the room the picture of despair. When the wind threatened to come to the $\mathrm{N} \mathrm{W}$ it appears he sent a message to Morice about sailing and which led the latter to send him an answer which I did not approve of, and this in the evening led to my giving Aplin a little [rowing?]. At this moment it is calm with rain.

Saturday July 8 Yesterday morning the weather was still unsettled and every appearance of its fixing in the East[war]d. We remained in great anxiety all the forenoon, I reading to her and she drawing till at noon it beeame threatened from the West[war]d and in half an hour became so decidedly so as to make their departure no longer doubtful. At one we had a melancholy luncheon - afterwards she put up her things - the vessel was ordered to be ready by four — and the carriage at the same time - Time lingered on [but] at last 
the sad moment arrived - A little after four A led her to the carriage[. W]e went down together and embarked. I remained till every thing was arranged and nothing left to be done - then ordered the boat, then with a broken heart bade a long adieu. On landing I looked once at the vessel and never saw her again - and here I must stop. It is unnecessary to record our feelings. They must be too deeply engrained on our hearts. - I immediately returned to Gov[ernmen]t House to my own room and there remained until ten oclock when I expected that that yacht would be out of sight from the Harbor - and then mounted my horse, which I ordered to be saddled in handing Mrs Aplin out of the carriage - rode to the Cottage. I avoided looking towards the sea, yet once my eye caught the glimmer of a sail — but whether her or not I cannot say - Miserable and wretched I rode slowly out - and immediately on arriving went to look for a yellow bird's nest which she was desirous of having taken and the birds reared for her - but the birds were gone - Johnston however shewed me two others which I determined to take care of for her - and accordingly this morning I visited them again - After Breakfast went \& got Stone to arrange some business and then returned. Mr Brenton followed me out - and I took him to shew him the yellow birds and they were gone - I have no doubt the cat takes them and she is to go away. - I walked this evening as far as Baly Haly in his return to town. How forlorn and miserable this place now appears. It is like a body without a soul.

Monday July 10th Yesterday morning being Sunday went to Town directly after breakfast - dressed and went to Church and for the first time without Mrs A for the last five months - How often did I look for her in her place, how often did I try to imagine her there. After Church ret[urne]d to my Study rec[eive]d visits from the Patersons \& Col[onel] Burke - after which I rode out to the Cottage and there sauntered about wretched and forlorn [and] visited those objects we had been at on precisely the same hour the Sunday before - Brenton came to dinner [and I] walked part of the way back with him in the evening - This being my day for receiving people who call — went to Gov[ernmen]t House after breakfast. Settled acc[oun]ts visited the gardens ordered out things \&c \&c then returned - Before breakfast cut down a tree sweet A wished to be taken down - Brenton came to dinner - walked back with him as far as Baly Haly - The wind has been to the East[war]d during the day. I trust the yacht has not got it - I cannot tell how much I feel for dear A, who is so invariably sick. -

Tuesday July 11 th - The wind [h] as again come to the West[war]d by which I trust the yacht will benefit and give sweet A. a quicker passage - Today has 
been very fine, during part of the forenoon employed myself in copying the last drawing she did in this cottage and which I mean to send to her. Mrs \& Miss Dunscomb came about five for the purpose of dining and about the same time Brenton. Had much conversation with Mrs D. about her - we dined at six being the hour fixed by A - who knows that they dined with me - for I marked on a paper three days on which they are to do so - After dinner we walked and at $1 / 2$ past 9 they went away. I accompanied Brenton home as far as Baly Haly -

[For the next two months, Cochrane spent most of his time at Virginia Cottage and continued to miss Mrs. Aplin. He noted each Friday how many weeks it had been since she left and took a walk in the cottage grounds at 4:00 p.m. on Sundays, the time of their last walk together. During this time he also visited Logy Bay, which he found "romantic" and noted that it "quite reminds me of a Robinson Crusoe scene in a play" (7 September), but most of his summer entries are concerned with the very hot weather. At the end of August and during the first part of September, his attentions shifted to the financial improprieties that led to the dismissal of Judge John William Molloy, Tucker's assistant; Cochrane, who had liked Molloy, was shocked and distressed.]

Tuesday September 5th - went to town this forenoon for the purpose of holding a Council and swearing in Mr Barking the Collector as a Member of it - also for the purpose of taking into consideration - certain memorials privy to the Suspension of Judge Molloy from his office in consequence of alleged dishonorable conduct on his part in procuring money and his inability to repay it and after reading all he had to say in exculpation of his conduct the Council were of opinion that he was unworthy of the situation he held and ought to be suspended and then suspended him accordingly — and a more persevering system of deliberate swindling - accompanied by a train of deliberate falsehoods is I hope rarely to be met with - and too clearly shews he is not a novice in such occupations. I am much pained at this discovery not only on account of his friends but on my own for I thought I had an acquisition in him - possessing as he does much talent and being very companionable - a most unpleasant task will devolve on me of acquainting his friends with his conduct.

[In mid-September, Cochrane began a tour of Conception Bay, which lasted nearly a month. Typically, he comments briefly on the towns that he visits, noting the number of religious establishments or other amenities; the entries between 17 and 21 September are slightly more detailed than most but otherwise representative. 
The most detailed description of the natural world occurs in his 7 October account of the "beaver house."]

Sunday September 17th - Yesterday morning we got under weigh and beat up the Southern shore landing for a short time at a place called Manuels. The whole of this coast is studded with fishing establishments at every few hundred yards and must be very populous. It appears they have never a clergyman among them. The Southern coast towards the beach is low but soon rises to a moderate height of hills immediately beyond which there is another range[. A]bout sunset we anchored in the NW arm of Holyrood where there is an Establishment belonging to the [house of Dawson?] Holyrood consists of two arms one SW \& the other NW each running about two miles up[. O]n the latter is the Establishment abreast of which vessels can be landlocked - directly we anchored we hauled the seine but had bad sport - this morning we anchored landed in the SW arm of Holyrood for the purpose of going to [?] down through a Path lately opened by Major Skinner[,] this run being in the direction of St Mary's Bay (the head of it - ) [T]hree horses were brought for us to ride - and here and there we were enabled to do so but the dismounting was so frequent that I at last took to walking[. T] he path lay along the E[ast] side of the river that empties itself into the Bay and after passing through the wood for about four miles we arrived at the foot of the Down and were beginning to ascend when the weather became very black and over cast and rained hard[. W]e took refuge under a large Broken stone which partially protected us and were here detained about an hour with every prospect of having to return to the Beach through a deluge when it cleared up and we ascended to the top of the Hill and from thence had a very extensive view principally consisting of a very uneven and hill country studded with numerous ponds and clothed with a great deal of fir wood — and to the East[war]d and North[war] $\mathrm{d}$ extensive Barrens or hills covered with a sort of heather - the down we were on extending from what I could learn to the SW about nine miles across which Lieut[enant] Munby went when he crossed over to St. Mary's Bay - having looked about for game without success we returned by the rode [sic] we came — and reached the yacht between half past five \& six - Mr [Connel?] dined with me.

Monday September 18 - we weighed at five this morning and ran off Russel Cove where I went on shore with two of the gentlemen to look at some lime rock which was distinctly to be seen and had had a few [Tons?] of lime taken from it[.] I brought some specimens off with me[. W]e then made sail and ran into the next Harbor to the North which is about two or three miles and which 
contains a good many fishing rooms with some apparently good comfortable houses and a very neat Catholic Chapel - from thence we beat up into Gasters Bay and ran up its SW arm called Salmon Cove which is very romantic in appearance and contains about four \& twenty fishing rooms - in the NW arm lays a rock[;] sailing out of this we ran to Colliers Bay - and when close off its southern point we picked up a man and his boat in which he had been upset — and sent him onshore in [tow?] of the Maria who had just returned to us we beat up Colliers Bay which is the deepest of any we have seen being four or five miles deep and a rock that broke laying in the channel end about $1 \frac{1 / 2}{2}$ miles from the entrance - This Bay is remarkably wild looking with few Establishments and almost as inferior to Gasters as the latter is to Harbor Main - we have anchored about 5 miles from the entrance in a Bight on the South[war]d side[.] I hauled the seine before dark but had little success - The country is remarkably wild looking and mountainous - with dwarf well packed fir trees

Tuesday September 19th - at day light we went on shore in the head of Colliers Bay to haul the seine as well as to fish with fly but had equally bad success both ways[. A]fter Breakfast we weighed with the intention of Trawling down the Bay which had been described to us as free from Rocks - but the nett [sic] had not been five minutes overboard before it was chequed [sic] by something and at last the trawl line broke - and we in vain swept for the end of the line and unless some fishermen to whom we have offered a reward for their trouble pick it up the seine is lost to us - after such bad luck we bore away for Brigus and anchored there in the afternoon where the good people saluted me with two guns that they had after which I went onshore attended by Mr Cozins the Magistrate and was surprised to find such a clean thriving looking place which contains more good houses than any that I have seen scattered over a considerable extent of ground upon these hills - Mr C has done a great deal for the place in the way of making roads schools \&c \&c. It contains about 800 resident inhabitants a Catholic \& Weslean [sic] Church[,] two Schoolmasters one schoolmistress - a Weslean minister and a Catholic one who visits occasionally - we ascended a high hill to the north of the town which looks down upon Port de Grave Bay - Bay Robert and Spaniards - a road is in contemplation between this and Port de Grave - Mr Cozins and two others dined with me. In answer to the question as to whether the farming interferes with the fishery they all tell me that were it not for the fishery farming many would with their families starve during the Winter. Sent the tender to $\mathrm{P}$ [ortugal?] Cove last night and she has rejoined us.

Wednesday September 20th - weighed from Brigus in the morning and 
stood for Port de Grave and Cupids Harbor within it - for the purpose of picking up Mr Cozins - and going out again in attempting which from Bafling winds we made a storm Board and ran on shore and had to lay a stream out to get off again - then we anchored and I went (attended by Mr C and a gentleman from Port de Grave who with others came to call upon me) tu a smalt narrow arm of the sea to a savannah country of some miles long which is ealled from the resemblance in color to that article metal - an idea prevailing that many years ago it had been up a small arm of the sea in the SW corner of the Bay and which runs about $2^{1 / 2}$ miles up the Country and leads near to a savannah country - called by the Country people the golds from the colour of wheat that grows in it - there is an idea that it was in ancient time in Cultivation and that ridges which pass through it indicate that it had formerly been ploughed - I however do not think that such is the case and attribute the formation of the ridges to the overflowing of a river which passes on one side of it - an old farrier who accompanied us informed me that this ground extended three or four miles and is of a breadth of about two hundred yards - the soil appeared a mixture of sand and clay - and of considerable depth and is I understand free from stone[. T] he old farrier informed me that further up the river which runs through this ground there are very extensive ridges of remarkably good soil[. O]n my way down I landed at two or three places and found the soil apparently good and tolerably free from stone[. C]ertainly the soil on the northern side of the Bay is[,] as far as we have gone[,] considerably better than that on the southern - on my way down the Bay I landed on the South side and walked across the Isthmus to Cupids - Mr Cousins [sic] and Mr [Prowse?] dined with me - the other gentlemen who called were asked but from some mistake did not come[.]

Thursday September 21 - weighed at day light and ran over to Bareneed where I landed and walked from thence to the small town of Port de Grave[;] indeed the two join[. T] hey are situated upon a narrow isthmus of land which separates this from Bay Robert[. I]t is an arrid [sic] stoney point but the people have taken advantage of every spot of ground to cultivate and some of their patches do them much credit - there is an Episcopal Church at Bareneed and a Catholic, an Episcopal and a Wesleyan Chapel at Port de Grave - there is also a Wesleyan Chapel at Cupids - the gentlemen here are of the same opinion as at every place where I have been[,] that the people would starve were it not for the cultivation[,] and are quite at variance with some people about St. Johns who have told me that they considered the loss by not going earlier to the fishery was not compensated by the cultivation - but to my 
mind the advantage of the cultivation is this that when the fishery is by chance bad the poorer people who rear vegetables have something to live upon[. T] hose who do not cultivate must starve - Cupids is a small village prettily situated and thriving[. T] he harbor is considered very safe but it is difficult as we experienced to get out of it when blowing fresh from the NW - the population in all these Bays is on the increase - not from strangers but by Births - having seen what was to be seen in Port de Grave we embarked and sailed for Bay Roberts into which altho only the distance of three or four miles we did not arrive for want of wind until near noon - we landed at the village and went into an unfinished Episcopal and a similarly situated Wesleyan Church and saw in passing a small childrens school and I was glad to see that the children were so clean and well kept - it is a miserable village — and there being nothing to be seen we embarked for the purpose of running down to Harbor Grace but it continued calm all day until Evening when a light air came to our assistance to convey the yacht to anchorage in the head of Bay Robert[s. W] hile the vessel was going in we landed and walked accross [sic] the Isthmus until we got a Picturesque view of Spaniards Bay[. I]n the course of the Evening the Maria who had been dispatched to Harbor Grace returned bringing Dr [Sterling?] in her - to whom I had to give a bed on board[.]

Saturday October 7 - At daylight yesterday Morning we weighed again and stood up to the head of the Sound and approached the Bar which divides this from the water that encompasses the other half of Random Island and then anchored - when we went aboard the Boat and rowed across the Bar on which there was not above five feet water we saw quantities of wild geese and ducks but too shy to allow us to approach them - we then rowed to a bight where some wood cutting Boats were laying and met with a farmer who had been up there for about a weeks gaming and had gotten three wild geese and the same number of Beaver - finding from him that the beaver house was not far from the shore and never having seen one I got him to take us there - and landing at a place called Georges Brook we went up into the Country through woods and marshes for two miles and a half and found the house situated in a marshy Island in the middle of a pond to which we had to get by crossing a single stick from which had a foot slipped we should have gone up to the chin in water the house was about four feet in height and composed of mud and sticks firmly and curiously locked together - but this was all we could see of it and never having seen the interior of one I resolved to return again on ascending 
the other arm of the Sound and open it - on returning to the Beach we found the tide out - and the wind blowing a gale from the SW and had to wade nearly half a mile to the Boat and then to row to windward and bear down upon the Brig which we found had driven and was obliged to let go a second anchor - and altho the wind down was fair yet it was thought most prudent not to weigh for fear of drifting upon shoal water astern of us - in taking up the anchor I therefore determined to lay there the night and being detained so long purposed going to the Beaver house at day light this morning[. W]e accordingly set off as soon as we were ready[,] accompanied by men with shovels \&c and opened the house about the centre by making a section through it and came to a sort of room or shelf in a semicircular form about two and a half feet broad and cutting off the segment of a circle of perhaps five feet long[,] the roof concave and in the centre about $2^{1 / 2}$ feet high. On one part of the floor (which like the rest of the building consisted of sticks well intermixed and plaistered with mud) lay a collection of small splinters of wood a little larger than tooth picks and in another some leaves as if for beds[. T] his shelf or room gradually sloped down to the lower place which was full of water and communicated with the pond by a tunnel sufficiently large for the Beaver to pass through - I was disappointed in not seeing a second Tier of rooms which some houses have as well as subdivisions in them - Captain Buchan who has seen others states that this one is small in comparison with many[. T] he most curious part of the operation appeared to me to be the size of the sticks they cut down and carry off[. I] saw the trunk of a tree which by the marks of the teeth on it had been clearly cut down by them - at least three inches in diameter - and of which there was not a branch remaining - and this after having got the tree down they must have cut in junks and then have carried off [. P]art of the stream which is a considerable one was still dammed up by them and I observed a quantity of material which was washed away by the floods and with which they had stopped the remainder of it[. T]his operation I believe they perform for the purpose of keeping their lower room full of water - there being much more scientific observations of this curious animal than I can give I will only add that they have only two upper and two lower teeth the latter very long - with which to perform this operation $-[\mathrm{O}] \mathrm{n}$ reembarking we immediately got underweigh and have been all day working down the Sound with the wind directly against us and during the afternoon a drizzling rain we are now anchored for the night in a place called upper Lance Cove - I have found in course of conversation with Captain Buchan that very unintentionally I have done some injury to the hunter by opening the beaver house as it appears 
they obtain a continual supply from it by never killing out the old stock and that this man has resorted to it for ten years and that in all likelihood the Beaver will now desert it - and when a hunter finds a house he carefully conceals the knowledge from everyone - under these circumstances I shall certainly send him a remuneration so that he may not suffer by his confidence in me - to day I complete my first year in Newfoundland -

[Back in St. John's, Cochrane settled into a social routine similar to that of the previous winter. The silver thaw that he saw on New Year's Eve and the celebrations around the Bishop's "haul" were the two events of the winter that led him to make unusually detailed journal entries.]

Sunday Dec[embe]r 31[s]t ... This morning there was a silver thaw - but which I should call rather a silver frost - perhaps one of the most unique sights in a landscape that is to be met with — it is the drizzling rain or moisture freezing as it falls upon the branches of the trees - as fast as one coat of moisture is frozen another follows until each branch is so completely coated as to appear as if the whole were coated in glass - taking the exact form or shape of the leaf or branch with all its inequalities - I scarcely know whether most to admire the deciduous trees whose branches lost in the mass of ice around them look precisely like imitation trees in glass or the fir leafs which covered with ice partaking of all its forms resembling what I should suppose [inserted: would be the appearance of] a collection of emeralds embedded in a covering of the finest glass - these silver thaws are more common early in spring than at this time of the year and when immediately followed by bright sunshine the various prismatic colours they assume when waving too [sic] \& fro - surpass I am told anything that can be imagined - the quantity of ice constantly increases while the state of the weather lasts - until the weight of it breaks the branches and destroys the tree but fortunately it does not often continue long enough to produce the injury that would otherwise occur. The ground was so slippery and icy that altho there was no snow I sleighed into town without difficulty

[February 8] To day the Catholic Bishop got what is called his haul. That is all the lower class of Catholics and many of other persuasions bring him from the woods as much wood for fuel as their catamarans can carry and there is a great emulation among them who shall make the greatest offering - for which purpose in many cases several combine together and lashing their sledges abreast 
raise their pile of wood to an immense height - which is general [sic] prepared in the town or immediate neighbourhood - The top is commonly surmounted with flags and occasionally a fiddler and then with men supporting it by ropes and drawn by men it proceeds to the Bishops residence - one pile was raised above eighteen feet high and in attempting to move it it fell over, the fate that often attends others and is frequently attended by injury to several of the parties - Today I hear some accidents happened, one man having his thigh broken - On these occasions the Bishop has to provide the parties with rum. In consequence the town becomes a scene of drunkenness - and I believe some perish on such events - from laying in their drunken state exposed to the inclemency of the weather - The haul of wood is reckoned sufficient to supply his wants for four or five years when they give him another. It is four years since his last haul -

[On June 21, Cochrane started an extended tour down the south coast of the Avalon and through Placentia and Fortune Bays. His first stop was Trepassey.]

... we landed at this now almost deserted spot where we could only see some of the remains of its former prosperity. Mr Simms ${ }^{42}$ brother has resided here for some time and altho absent himself we found his wife and children as well as his mother - the former is a healthy looking young woman who in the evening very obligingly sent us off some butter and Devonshire cream for which this place is famed. We walked up to a conical hill standing upon the Peninsula and commanding the water on both sides where once upon a time a fort was established, as two nine pounders testify, which we found laying there. Our curiosity was soon satisfied here and we crossed over to the NW arm and walked up a tolerably large stream that there empties itself into the sea in the hope of finding some trout - those of the party who remained at its mouth were the most fortunate - but the most lucky did not meet with the success we had been led to expect and returned to a late dinner; some of the party complaining much of the annoyance they had met with from the mosquitos and sand flies - the hills in the neighbourhood are clothed with stunted firs and birches - and the interior appears to be one vast extent of barrens - in the vicinity of the village there are some good fields of grass - and most of the people keep cattle -

[The journey was hampered by foggy conditions, but after being delayed in their first attempts to round Cape St. Mary's, they reached Placentia Bay on 27 June and then continued along the eastern coast of the Avalon Peninsula. Many of the 
entries are simply records of the relative difficulty or ease of entering a harbour or comments on the weather; I have omitted passages of that sort.]

[Tuesday July 3] . . . we weighed and sailed down between the islands to Merasheen - the view was beautiful - the differently formed islands at various distances and of various sizes scattered about enlivened by the boats passing to and fro made an interesting panorama. The day was delightful and probably the more enjoyed from the wretched weather we had previously suffered from - about one we got off Merasheen harbor and finding that from its narrowness there would be difficulty in entering and departing I confined my visit to landing in the boat and was met by Mr [Keough?] the proprietor and Mr Henderson of St. John's - and we were taken over to the place of his residence and presented to Mrs K. who seems a nice little woman and is extremely well spoken of - Mr K has been unfortunate in trade but is now redeeming himself and has hitherto had a very prosperous fishing. This is the only fishing Establishment upon this Island and is placed at its SW end. He employs a few servants and supplies I forget how many planters - the island like all the rest of the coast we have come along is with the exception of occasional small spots very barren. The surface in most parts seems to be a bed of stone underneath covered by moss or bog - wherever the planters can find a small spot they cultivate it - as we passed along the shore we saw Establishments or rather fishing rooms in [?], on Sound Island - Woody Island and on several others - and in most cases they can take their fish without going far from home ....

[July 5, in Placentia] . . . We went up the SE arm to a brook where a quantity of smelts are every season to be taken and here we actually did what I had often before heard of but never done and that is caught fish with our hands, which we did with perfect facility particularly when they attempted to take refuge under a stone. They appeared almost tame or stupid. At that same time when pursued or frightened they were swift enough - in the same stream we saw a quantity of little fish called thorn-backs which are of no use for the purpose of food - we were much disappointed in the taste of our smelts at dinner being much inferior to those taken at Come by Chance and which we attributed to their having recently spawned $-\ldots$.

[Saturday July 8 entry; describing the previous Tuesday] We landed at Oderin for about an hour and having ascended one of its principal heights from which we could command a pretty extensive view of this part of the Bay, whose indented shores and numerous islands possess the same character for rugged varied height and sterility as the rest of the western shore - having received a Pilot from the Manager of the Establishment — we sailed again for 


\section{Perkins}

Burin, passing between the Islands and Western rocks - and from the various breakers we saw and $[s i c]$ number of broken rocks mentioned by the pilot but not noticed in the charts - (which observation is equally applicable to other parts of the Bay) I am convinced of the inaccuracy of our charts and the impropriety of coasting about without a pilot - the wind which had hitherto favored us became variable with occasional rain and it was dark before we reached Burin Island where it fell nearly calm, leaving a heavy swell — and after towing with a boat ahead and an occasional air, we got to an anchorage in Ship Cove about Eleven oclock at night - a remarkably snug harbor, and perfectly land locked but like most others on this coast with deep water - yesterday morning we landed and visited another good and well regulated Establishment of Messrs Spurriers $^{43}$ - and myself and some of the least lazy of my party ascended a very steep hill at the back of the River from whence we had a very commanding view of the various windings of this Bay and the Islands about it - but as far as the Eye could reach the land was rugged and unequally high shewing one bed of rock partially covered with a bit of moss or heath - and here and there a miserably situated fir and patch of verdure in hollows where the mountain torrent has deposited its alluvial soil which there in the vicinity have been converted by the Inhabitants into potato gardens - at some distance in the interior I am told tolerably good wood is to be had and as witch hazel is said to be among it - probably the soil may be better - after descending the hill we visited the jail and court house which I found in a dilapidated state. I was there met by $\mathrm{Mr}$ Hooper the Magistrate ${ }^{44}$ who had come over from Mortier and was agreeably surprised to find Messrs [Keough?] and Henderson with him who seeing him us pass down the day before - followed us here - they with the young Gentleman who shewed me the Establishment dined with me - Burin is the most populated spot on this side of the Bay - and contains I believe scattered about in its various safe coves and harbors 8 or 9 hundred Inhabitants - but without school, doctor, Episcopal church Establishment or any necessary institution - the particulars of which having noticed elsewhere I shall not here repeat - this morning we went onshore to hear Mr Pering ${ }^{45}$ perform divine service in the Methodist Chapel which the minister had given up for the occasion - there were assembled about a hundred people upon the occasion - all very decently and correctly dressed. I was however sorry to learn upon enquiring that so large a congregation had not been collected together for a length of time[,] the usual number being about five and twenty though the church is calculated to contain about three hundred - the smallness of the number is not altogether to be attributed to the circumstance of its being a 
meeting house as Episcopalians equally attend in the absence of a regular clergyman and the $\mathrm{M}$ [ethodist] Minister to meet their wish reads in the forenoon the Church of England service[. A]fter the people had dined we weighed anchor to sail out of the western passage and had reached its entrance when the wind fell and we were obliged to anchor for the night -

Thursday July 10th - at daylight on Monday we got under sail with a light breeze and beat down towards Little St. Lawrence and in the afternoon being becalmed off the Entrance we went in in the boat and landed at the Establishment of the house of Newman for the purpose of procuring a Pilot to take us into Fortune bay and having accomplished that object we walked over to Great St. Lawrence a distance of about a mile where we saw a similar arm of the sea to the one we had come from with about twenty rooms in it - having heard that the schoolmaster had taken upon himself to marry people I sent for him - and while waiting for him received two complaints from parties - of some of their little gardens having been unjustly taken from them - when the schoolmaster came I found a poor sickly creature apparently far gone in disease and from his account of himself as much arising from poverty of living and misery as anything else - he seemed much frightened when taken to account for marrying[,] protesting that he did it for the best, there being no other person to perform the ceremony - after having warned him against doing so again and given him a trifle for his family we recrossed the Isthmus and made the best of our way to the ship (who had not been able to get in) followed by the Pilot and it was our intention immediately to proceed on but the wind failed and in the course of the night we drifted so far into the Bay that in the morning we were obliged to come to anchor here in Little St. Lawrence and had scarcely anchored when a thick fog came on - it continued all day but in the Evening I went over again to G[rea]t St. Lawrence accompanied by the [?] \& Capt[ain] Morice and while the latter went into some cottages to visit [sick?] people we got into conversation with the wife of a fisherman who called herself Pike whose observations and conversation would have done credit to a much higher station in life - She stated that she was born at a neighbouring harbor where her father still lives and laid great Emphasis on his being an Englishman born - she was above the middle height; without being handsome had a pleasing expression of countenance when she spoke - with an unembarrassed though not a forward manner - She was ignorant of who we were and spoke very feelingly and with much point of their situation in Newfoundland - She lamented that no Episcopal ever or scarcely ever visited them and said that Newfoundland was thought nothing of at home, on speaking 
on the subject of people getting married by improper persons she said but what can people do - no minister ever comes among us - people cannot wait for ever[. F]or my part altho it may not be lawful - I think if we cannot get a minister to come among us - the word of God read by any other person will be just as good and holy - shortly after on making enquiry about the curing their fish she said my sister and [sic] law and I cut the throat and head and when salted we put it out to dry - then looking at the stage on which the fish was throwing up she said observed presently I must go to my work there [inserted above: that is the way we go on] and this with a look and expression which if she we had not known she had been brought up to such labor - would have said such work is not suitable to me, fortune has placed me beneath my station - indeed her dress and whole deportment would not lead you to suspect her accustomed to laborious unfeminine toil - The poor people here all suffered from measles, neither old nor young have escaped and altho the deaths have been few, the malady has been a severe affliction to many families where the men having taken cold after them have been prevented going to the fishery and making their summer harvest — one poor man had been six weeks confined to the house, and his family living upon the charity of their neighbours - after Morris [sic] eould had done all he could - we returned to the boat and in our walk accross [sic] were accompanied by a man and his wife who were taking a child over for the purpose of being with some others who had gone before - christened by Mr Pering. We took them accross [sic] the water and having ordered some flannel to be bought for the schoolmaster who was also there with a child to be christened we returned on board to dinner- ...

[On the next day, 11 July, they set out for Harbour Breton, after which:] We proceeded on in a direction for Poile Bay intending to go there for the purpose of getting deer - but the weather appeared so unsettled and no one had been there but Capt[ain] Buchan who had little recollection of it, I determined to make for the Ramea Islands which appeared by the Book of directions to contain a good harbor and which was confirmed by Captain Buchan who stated his having been there when in command of the Grasshopper. W]e accordingly made sail for them, passing to the Westward of the Penguin Islands and leaving the Ramea Rocks to the Westward of us - and reached the snug little harbor at the Rameas [\& took?] anchor before a thick fog came on - Captain $B$ had told us that there were many Inhabitants on them - with other particulars about them - but in vain did we look as we approached for any thing like the habitation of man[;] not a boat was to be seen - Captain B was equally at 
a loss as to where they were and as to the place of anchoring and at last discovered he must have made a mistake and that the [Bourgeois?] Isle ${ }^{46}$ must have been the place they put into - so much for nautical reminiscence - after anchoring I went with one or two of the gentlemen in the little boat to explore[,] as the pilot said he believed some residents were here[,] and seeing something like a flag pole with a vane on it upon a hillock. [W] landed and in a little cove found two families, Father and son, who with another son established about $1 / 4$ of a mile off we ascertained made up the population of the islands. We went into the Cottage of the old people which though poor as to construction was very clean [,] the dresser and cupboards tricked out with all the neatness of an English peasant - we found he had been resident here twenty years, had had 12 children two of whom with their children formed his society here. He employs two sailing boats and has three servants in his employ — but we were sorry to learn had been unsuccessful this season - he keeps a couple of cows which obliges him to pass his winters here but his sons go into the woods if they can be so called in the month of October or November and return in April - To our enquiries as to whether they grew potatoes he stated that the soil would not yield them or do little more than repay what they sowed. This is the first instance we have found where that vegetable could not be grown ....

[With some difficulty, they anchor in White Bear Bay to wait out fog and calm.]

Monday July 16 - it was calm and foggy all night and in the forenoon just as we were going to have Church the fog cleared away and a Breeze springing up we got out of the cove and made sail in the hope of getting out to sea but we had scarcely beat to the mouth of the Bay when the fog came on as thick as ever and obliged us to put back again — but wishing if possible to avoid going so far up the Bay I sent the Pilot onshore at the North East end of Bear Island to enquire of the fishermen living there if they knew of anchorage nearer - when they came off and pointed out an anchorage of from Ten to twelve $f[a t h o] m$ on a ridge or Bank extending from the NE p[oin]t to a small Island laying to the North[war]d of it - after anchoring I landed on the Island and visited the only two families upon [inserted: them] — they were brothers with their wifes [sic] and children and another brother living with them - we found the house which we went into though very poor yet quite clean, as were all its inmates on the table laying a Bible and much [tattered?] prayer book — which led to my making enquiries as to their attention to their religious duties - I found that the only member of either family who could originally read was one of the wives but who it appears had imparted all her stock of knowledge to the other 
members of the family which was confined to that of reading print - to writing themselves or reading that of others - even their merchants accounts[,] they had not aspired - but of the talent entrusted to them they had made the noblest use - for I found that every evening before retiring to rest - each family had their prayers and of a Sunday they met together in the morning and evening for the same purpose - with great simplicity they added that they were ignorant how the Church Service should properly be performed never having even seen a Minister but that the woman before mentioned had some little knowledge of it and performed it to the best of her abilities, and the elder brother added that he hoped they did not do wrong in reading for themselves having no minister to read for them - I need not add what assurances I gave them of the praiseworthiness of their conduct. They said that last year they had not been successful and the elder brother stated that for the first time for twelve years he had got into debt to his merchant L.1 $\backslash 11-$ As an encouragement to him not to be cast down at such a casualty [I said] that I would discharge that debt and promised to send to each family the Bible and prayer Book for which they seemed most thankful - it appeared that they had not been regularly married but it having taken place before the late marriage act it would be probably binding. ${ }^{47}$ Nor had their children been regularly christened but they did not seem inclined to have the ceremony repeated. I was much struck with the conduct of these poor people and felt almost humiliated to think that they without education - example - or precepts but from the dictates of their own feelings - first undergone the task of learning from one scarcely able to read herself and then devoted their talent to the worship of their maker with an earnestness not always to be met with among those who are pleased to style themselves their betters - Oh God how unsearchable are all thy ways - while we possessing worldly consideration look down with pride upon our fellow creatures - who happen to be less capable of tracing their lineage a few years back or possessing less of worldly wealth than ourselves - thou viewest us with very different eyes - and judge with very different judgement to men's judgement who are the great and who the small - I confess these poor people have humbled me in my own eyes and shewn an example which I shall do well to follow -

I looked over one of their Merchants accompts [sic] and could not discover one shop of spirits in it and on making enquiry they told me that for years they had not bought any - we returned outward pleased with our visit - and after dinner Mr Pering attended by [?] went onshore to see these people and perform some part of the Church service with them $-\mathrm{A}$ fog came on again at 
night but this forenoon clearing away we got under sail and in vain attempted to get out[;] the wind failed or rather came in and a fog with it that we were obliged to return to our former birth [sic]. I however trust we shall have better luck tomorrow as a good breeze has just sprung up from the ENE - Today we were visited by a family of Indians on their way from Fortune Bay to their wigwams at the head of this - they consisted of two brothers, their wives and children. The men spoke tolerable English and we had a good deal of conversation with them - we found that they are not Mickmack but Mountaineer Indians, their whole number in this Bay being about 30 or 40 , the remainder of them having been also away on an excursion - but expected back tomorrow - The men were slight made, dark mulatto color, tolerably high cheek bones and broad at that part of their face, with rather a roman nose but spreading a little at the nostril and one of them had rather keen eyes. They are reckoned a very active race, more so than the Mic Macs - and their make corresponds with that perfectly.

Wednesday July 18th - Yesterday morning there was a fine strong Breeze from the NE of which we took advantage by weighing shortly after day light - it however did not long stand our friend for we had scarcely reached the magnetic rocks when it died away and became variable and we had not advanced beyond Cape La Hune at sunset - we saw in the course of the day the Magnetic and Little River - all the Whale rocks - which make this part of the coast very unsafe in foggy weather - A strong breeze sprang up in the Evening from the Eastward which made it a dead beat to Harbor Britain $[s i c]$ and in the morning we had only advanced as far as Pass Island - [T] he Coast all the way from White Bear Bay to the entrance of the Bay of Despair is one mass of high bold rugged rocks, the highest part being about Cape La Hune and stated by Mr Bullock the surveyor to be 991 feet in altitude. Here and there a little verdure shews itself in the crevices of the rock which otherwise is perfectly barren; towards Cape La Hune it is generally of a reddish colour, about Pass Island and on that side of Connaigre Bay the land is low and smooth with a green moss generally covering it - but from the other side to Harbor Britain it is again high and very sterile....

Friday July 20th - at daylight yesterday morning we got under weigh with a fine breeze from the North[war]d and crossing over to the shores of Fortune bay sailed along them until we arrived at Point May - the whole of which coast is comparatively low and even, covered with apparently a verdant moss - which affords some pasturage for cattle - and here and there were interspersed about some knots of small fir trees - the soundings on this part 
of the coast also extend considerably farther off the land than at any other part[. A]t a place called Little Garnish we observed one or two fishing rooms and one or two more between that and Grand Bank at which there is a small village containing several fishing rooms and as I understand about four hundred Inhabitants. About four miles from there is another small settlement at Fortune containing about one hundred and fifty - From point May we stood over for the Island of St. Peter's [St. Pierre] — to pay a visit to the Commandante there - that I might see what sort of place it was as well as to have some conversation with him on the subject of the complaint that had repeatedly been made of encroachments of the part of their fishermen. I was also influenced in my decision to touch there by perceiving that my visitors had a desire to see the place. We accordingly stood over and reached the anchorage about 2 oclock where I found the tender who we had dispatched in the morning[. I] mmediately on anchoring I saluted which was immediately returned and shortly after the Captain of the Port and then an officer from the Captain of an Armée en fleete came onboard to offer civilities \&c. to which I responded by stating my intention of landing to pay my respects to the Commendante - We accordingly landed for that purpose the yacht saluting me[. O]n pushing off we were received by the Governor or administrator at the wharf attended by his Etat major and others of his little colony - and after mutual interchanges of civilities and introduction of our respective parties we proceeded to the Gov[ernmen]t house escorted by 4 Gens D'Armes who we had previously observed escorting him down - On our arrival at the house we were seated and then offered wine[. A]fter the formalities of a first reception were over and the conversation became a little general I alluded to the subject of my stay and being anxious to get off as soon as possible I availed myself of his invitation to dinner to beg that he would dine with me on that day and that I would do so with him as $[s i c]$ today and then sail in the evening but subsequently thinking that his entertainment would be long and late, I got him to allow me to turn it into a breakfast - I then begged to be allowed to look about and see the little that was to be seen in this wretched place which in point of fact consists of the Gov[ernmen]t house and about three other indifferent dwellings, a Catholic Church and a parcel of miserable huts furnish'd up by those who remain in the Island to let as lodgings to those who come out in the spring. There are but two or three fishing stages in the Island the fish being in every other case cut and split at tables on the beach and then carried into little huts close in the rear where it is salted and then dried on the beach, flakes not being in use in the Island - The fishing is carried on in the most economical manner, 
the people eating the heads which our people throw away - their gov[ernmen]t allows a bounty of 15 francs p[e]r Quintal upon all fish exported direct to the West Indies and 20 upon that which goes there from France. They also give to the fitter out of every vessel in this trade fifty francs [?] for each man of their crew. Their whole export last year including all their fishing except that of [?] amounted to about seventy thousand quintals of which about twelve were salted green - The Island is one entire rock without a tree upon it and their only verdure some mossy grass on which they manage to feed a few cows and sheep. By treaty they can have no fortifications and there is I believe but a couple of guns - and his forces consist of the four Gens d'Arme already mentioned. It is governed by an administrator but who is not entitled to the appellation of Gov[ernor]. He is named Borius, ${ }^{48}$ is a Captaine de Frigate and a man of about 54 years of age - There is a harbor and roadstead. The former has a Bar with 11 feet at high water spring tides, the latter is exposed to Easterly winds - After seeing the little that was to be seen we went on board and just before dinner was followed by Mr Borius[,] the Captain of the Armée en fleete, the captaine du post and Commissaires. I had prevented the former coming to return my visit as he wished to do before dinner both because I thought it unnecessary and as it rained and had done so since we arrived. They remained with me till about Ten oclock and then returned onshore between the showers - This morning in conformity to my promise I went onshore to breakfast, but to avoid any further ceremony landed without a flag flying and without the town[. T] he old Gentleman however kept too good a lookout and saluted and came along the Beach to meet us. All his party was assembled which consisted of his own Etat and that of the ship and after waiting about an hour we sat down to a second breakfast or rather a dinner of which nolens volens we were obliged to eat as if we had starved for a month and really the things were so well cooked that to a certain extent willingly obedient to their entreaties our [seance?] lasted full two hours when we broke up and as the wind was fair, and the day advancing - so soon as some of my party had made a few purchases, I took leave of my kind host after having had a long conversation with him on the subject of his fisheries and their interference with ours and that of their cutting wood upon our coasts and as wood is essential to them I promised altho I could not recommend that they should cut it themselves that on my arrival in England I would recommend to Gov[ernmen]t to permit that article to be carried to them - soon as we got onboard we got under sail and being taken out of the harbor roadstead by the Captain of the Post and clearing the shoals he took his leave and we proceeded on our course and are now 
abreast of the Chapeau rouge having passed along the coast about Lamaline which in all respects resembles what we passed in sailing along to Point May - we saw the village of Lamaline which appeared to contain about five and twenty dwelling houses and Ten or twelve rooms[. T] he tender was laying at anchor there having in the morning taken over Mr Pering to enable him to christen some children and will follow us to Ferryland. I must not omit to mention that the cause of the Armee en flote being in the harbor was her having struck upon a rock at the distance of a League SW from St Pierre on which he informs me there is only twelve feet water with deep water all round and that it is twice the size of a boat. I am sorry to say I have forgotten to ask him the different bearings of it and fear the rest of the nautical men of my party have been equally forgetful - the Captain's name is Belanger.

[On Saturday the 21st they rounded Cape St. Mary's; delayed by bad weather, they reached Ferryland on the 22nd, where Cochrane spent some time with the Carters. They arrived in St. John's the following week, and on 12 October, Cochrane sailed for England on the Forte. His main private preoccupation around the time of his return to England appears to have been his family, as he had been away from his children for more than two years, and his father had been suffering from illness during that time. Public correspondence in the Colonial Office records (CO 194/76), however, indicates Cochrane's continuing engagement with Newfoundland issues even during his leave. Letters to William Huskisson and Sir George Murray, the Secretaries of State for the Colonies, cover matters ranging from Cochrane's salary to the furnishing of Government House to the grievances with St. Pierre over wood-cutting issues. This gap between public duties and private interests and reflections is maintained in the later journals, but by that time Newfoundland appears to have lost some of the novelty that attracted Cochrane's attention during the first two years of his residence.]

\section{NOTES}

1 The London-based Newfoundland Schools Society noted at the time that taking the government of the island "out of the hands of naval administration" and giving it to "a Civil Government and Council" provided a "happy" opportunity for improving local education: "Newfoundland Schools," The Times (London), 14 July 1824. Cochrane himself noted the presence or absence of churches and schools in most of the settlements he visited, and - as some of the early entries reprinted here indicate - began his governorship by looking into sites for new or improved roads. 


\section{Thomas Cochrane and Newfoundland in the 1820s 165}

2 Other glimpses of St. John's and Newfoundland society from this period and later, from a French perspective, are found in Scott Jamieson and Anne Thareau, trans. and eds., French Visitors to Newfoundland: An Anthology of Nineteenth-Century Travel Writings, original French edition ed. Ronald Rompkey (St. John's: ISER Books, 2013). Eugène Ney, for example, writes: "On our visit, the Governor [Sir Thomas Cochrane] displayed great pomp and ceremony, like a miniature court of the King of England. The society members, it is said, are handpicked; the ladies are fresh and pretty and the most pleasant season one can spend there is winter, in spite of its harshness. They hold balls and put on plays, with the actors chosen chiefly from among the officers of the two regiments stationed there and those from the one or two warships that stay in port" (p. 66).

3 John Dundas Cochrane, Narrative of a Pedestrian Journey through Russia and Siberian Tartary, 2 vols. (London, 1824). Late in his life, Thomas Cochrane, Earl of Dundonald, published two ghost-written memoirs of his earlier military experiences, Narrative of Services in the Liberation of Chili, Peru and Brazil from Spanish and Portuguese Domination, 2 vols. (London: James Ridgway, 1859) and The Autobiography of a Seaman, 2 vols. (London: Richard Bentley, 1860).

4 For correspondence providing the full details of this incident, see the Colonial Office papers (available on microfilm) 194/72, ff. 229-94.

5 John Knox Laughton, "Sir Thomas Cochrane," The Dictionary of National Biography, vol. 11 (London: Smith, Elder \& Co, 1887), 175.

6 These articles appear on 6 Apr. 1816 and 9 Dec. 1817, respectively.

7 The Times, 12 Aug., 17 Oct. 1817.

8 Undated letter to Thomas Cochrane, National Library of Scotland, Edinburgh, MS $2350, \mathrm{f}$. 195. The letter is filed with correspondence of the mid- to late 1830s.

9 Thomas Cochrane, unpublished letters to Thomas Hyde Villiers, (26 Nov. 1826) and Sir George Murray (9 Oct. 1828), National Library of Scotland, Edinburgh, MS 2370, ff. 60-62 and 24-27. The letter to Murray was written, in part, to protest a salary cut, so some hyperbole is perhaps to be expected.

10 Anne Aplin was the younger of the two daughters of Philip D'Auvergne, a vice admiral in the British navy and the failed claimant of the estates and titles of the Duc de Bouillon, who had adopted D'Auvergne when the younger man was a prisoner of war in France in the 1770s. D'Auvergne died, probably by suicide, in 1816, following the final denial of his claim to the Bouillon estates.

11 Eliza Dunscombe, unpublished letter to Sir Thomas Cochrane, 13 Mar. 1827, National Library of Scotland, Edinburgh, MS 2350, f. 17v.

12 D. W. Prowse, History of Newfoundland from the English, Colonial and Foreign Records (Bowie, Md.: Heritage Books, 2003 [1895]), 424-26. To be fair to Cochrane, correspondence relating to his public duties preserved in the Colonial Office papers demonstrates that he did maintain an active work life: for example, a long summary of his letters to the Secretary of State during the years before his first leave (CO 194/76, ff. 172-181v.) gives a sense of his duties in reference to the economic, military, and social life of the island. 


\section{Perkins}

13 Nicholas Lockyer (1778-1847), captain from 1824 to 1827 of the Romney, on which Cochrane sailed to Newfoundland. The Grasshopper, mentioned a few lines later, had arrived in Newfoundland from Halifax under the command of John George Aplin (c. 1790-1861); some years before it had been in the Newfoundland service under the command of David Buchan.

14 Lieutenant Colonel Thomas K. Burke (c. 1763-1837), the military commander in Newfoundland at that time. He became the centre of controversy when he was unable to take his seat on Cochrane's council because his Catholicism prevented him from taking the required oaths.

15 Unidentified.

16 Unidentified; perhaps the head of the council that had just been sworn in.

17 William Thomas Skinner (1780-1829), an officer in the Royal Artillery. His betterknown father, Thomas Skinner, had also served in the military in Newfoundland.

18 Thomas Scallon (1766-1830). Born in Ireland, Scallon arrived in Newfoundland in 1812 and was appointed to the Bishopric in 1816. He maintained generally cordial working relations with Cochrane during their overlapping terms of office.

19 Griffith George Lewis (1754-1859), who had served with the Royal Engineers in Newfoundland since 1819 and had been promoted to lieutenant colonel in 1825; Captain William Paterson (1783-1838), formerly of the Royal Navy (where he began his career as a midshipman under the command of Cochrane's father), had been appointed judge for the Labrador court in 1825 and served on the Executive Council between 1828 and 1831. Lewis's wife (mentioned in the entry for 9 May) was a Miss Fanny Bland; they married in St. John's in 1821. Paterson's wife Sarah (mentioned in the entry for 25 September) died in England in December 1827.

20 Francis Pickmore (c. 1756-1818), Governor of Newfoundland from 1816 until his death.

21 Edward Brabazon Brenton (1763-1845) was a Nova Scotia-born lawyer who came to Newfoundland as Cochrane's secretary and subsequently became an assistant judge in the Supreme Court.

22 Mary Tod Bruere Tucker, wife of Richard Alexander Tucker (1784-1868). Tucker, born in Bermuda, was the Chief Justice of Newfoundland from 1822 until 1833. He resigned after falling out with Cochrane over issues arising from the debates over representative government.

23 The writing is unclear, but there was a ship of this name that sailed out of Halifax in the mid-1820s.

24 The Forte, which Cochrane commanded before coming to Newfoundland.

25 George Farquhar Morice (c. 1791-1868), then in command of the Forte; he became notorious for having served as a second, the previous year, in what turned out to be the last duel fought in Newfoundland.

26 Lieutenant Colonel William Haly (c. 1771-1835), a native of Ireland who had served in the Irish Brigade; his estate formed what is now Bally Haly Country Club. Cochrane varies his spelling of Haly and Bally Haly throughout the journal, and I have followed his spellings in this transcription. 


\section{Thomas Cochrane and Newfoundland in the 1820s 167}

27 The Mountaineers, a melodrama by George Colman, premiered in England in 1793 and was a major hit because of John Philip Kemble's performance in the central role; Three Weeks after Marriage is an 1784 farce by Arthur Murphy.

28 Anne Elizabeth D’Auvergne Aplin (c. 1800-1879). See the introduction for a more detailed discussion of Mrs. Aplin and her relationship with Cochrane.

29 Presumably Anne Theresa Elizabeth Haly (c. 1807-1874), the eldest daughter of Colonel Haly and his wife, Ann Hutchings Haly (born c. 1777). She married Sir James Cochrane of Nova Scotia (no relation of Thomas), who became Chief Justice of Gibraltar.

30 John Dunscombe (1777-1847) was a Bermuda-born merchant who settled in St. John's in 1808 and became one of Cochrane's aides-de-camp before moving on to Montreal and Liverpool, where he died. Cochrane varies his spelling of the name, and I have followed Cochrane's practice in my transcription.

31 Presumably Captain William Pitt Canning (1802-1828), a son of the politician George Canning. (According to the 1827 Naval List, there were no other Royal Navy captains with that surname at that date.) Henry Litchfield (1786-1864), mentioned a few lines later, was the captain of the Orestes.

32 The implication here is that Cochrane is summoning Miss Haly to chaperone Mrs. Aplin so that she won't be compelled to accompany her husband when he arranges transfer of the command of the Grasshopper to Litchfield.

33 Miss Haly had a number of younger siblings, including Jane Lucy (b. 1809), Amelia Harriet (b. 1811), James Standish (b. 1813), Anastasia Emma (b. 1814), and William O'Grady (b. 1820). The Tuckers also had five living children at that time.

34 Augustus Wallet DesBarres was one of Tucker's two assistants in the judiciary when Cochrane arrived in Newfoundland; the other was John William Molloy, who was dismissed for financial impropriety in September.

35 A crossbar on a carriage used to attach the horses.

36 Litchfield was replaced in command of the Orestes by William Jones (d. 1846); Litchfield was promoted and sent to Halifax.

37 William Carter (1751-1840) of Ferryland served as a judge in the Vice Admiralty Court.

38 David Buchan (1780-1838) was the High Sheriff of Newfoundland at the time; he is now best known for his expeditions into the interior and his failed 1820 attempt to return Demasduit to the Red Indian Lake area.

39 According to the Oxford English Dictionary, a French bed was a bed with a scrolled headboard rather than the more usual four posts.

40 The name is unclear: possibly Arthur Holdsworth Brooking (d. 1836), who served as a customs collector and justice of the peace in St. John's in the 1820s and who is mentioned in the 5 September entry.

41 William Carson (1770-1843), a Scottish physician who emigrated to Newfoundland in 1808 , where he became very active in politics.

42 Presumably a reference to James Simms (1779-1863), an Englishman who settled in St. John's in 1809 and who also had at least one brother on the island. Beginning in 1825, he served as Attorney General of Newfoundland, replacing Molloy in that position when Molloy first joined the Supreme Court. 


\section{Perkins}

43 The Spurriers were a Dorsetshire merchant family who had, by that time, been involved in the Newfoundland fish trade for several generations.

44 William Hooper, appointed as justice of the peace for Burin in 1822.

45 Presumably Peter Pering, a missionary for the Society for the Propagation of the Gospel, who served in Ferryland between 1827 and 1829.

46 The word that Cochrane wrote is almost certainly "Bourgeois"; this could be his mistake for "Burgeo."

47 Given the chaotic state of marriage law in early Newfoundland, legislation passed in 1817 and 1824 legitimized irregular marriages that had been performed prior to 1817 (or, later, by 23 March 1825). See Trudi Johnson, "A Matter of Custom and Convenience': Marriage Law in Nineteenth-Century Newfoundland," Newfoundland and Labrador Studies 19, 2 (2003): paragraphs 19 and 23.

48 Augustin Valentin Borius (1772-1844) served as Commandant of St. Pierre from 1818 to 1819 and again from 1825 to 1828 . 


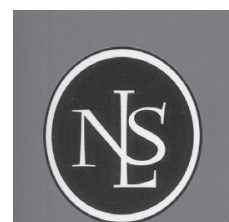

Moravian Beginnings in Labrador

Papers from a Symposium held in Makkovik and Hopedale

Edited by Hans Rollmann

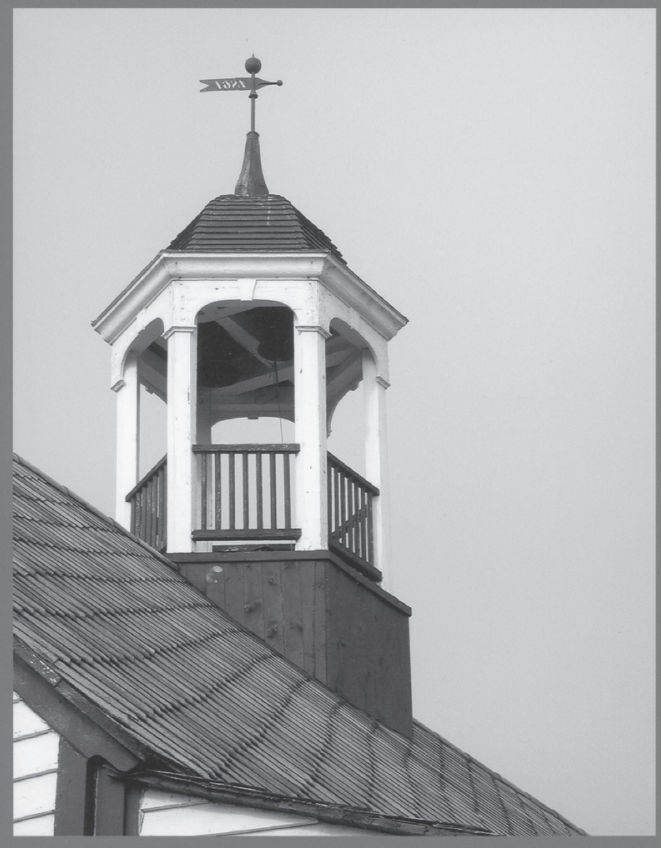

An Occasional Publication of Newfoundland and Labrador Studies, No. 2

Newfoundland and Labrador Studies publishes an Occasional Publications Series devoted to conference procedings, documents, and extended research notes. Regular subscriptions do not cover the cost of Occasional Publications, which must be purchased separately.

The second volume in the series is now available, entitled Moravian Beginnings in Labrador. It contains papers from a symposium held in Makkovik and Hopedale. The cost is $\$ 20.00$ Canadian, plus postage. To order, contact Newfoundland and Labrador Studies at 709864 2144, www.mun.ca/nls or email: nlstudies@mun.ca. The mailing address is Newfoundland and Labrador Studies, Faculty of Arts Publications, Memorial University of Newfoundland, St. John's, NL, A1C 5S7. 